\title{
CONTEXT MATTERS: THE IMPORTANCE OF UNIVERSITY AND FAMILY FOR YOUNG NASCENT ENTREPRENEURS
}

\author{
L. F. EDELMAN, T. MANOLOVA \\ Management Department, Bentley University, $U S A^{\text {a }}$
}

\section{G. SHIROKOVA}

Graduate School of Management, St. Petersburg University, Russia ${ }^{\text {b }}$ Department of Management, National Research University Higher School of Economics, St. Petersburg, Russia

\section{T. TSUKANOVA}

Graduate School of Management, St. Petersburg University, Russia ${ }^{\mathrm{b}}$

\begin{abstract}
Nascent entrepreneurs are those individuals who engage in start-up activities as part of the process of starting a new venture. In many cases, these activities lead to successful founding, but in some situations, the entrepreneur's initial ideas go unrealized because the new venture cannot mobilize the necessary resources needed to create a fledging firm. In this paper, we look at the impact of the family and university social context on young student nascent entrepreneurs. Our findings based on Global University Entrepreneurial Spirit Students' Survey (GUESSS) wave in 2011 suggest that both family and university have a significant impact on the entrepreneurs' progress through the venturing process. However, when we take a finergrained look, we find surprising gender differences. Female entrepreneurs rely on their strong family ties for support; however, they are also able to better utilize their weaker university connections to make progress through the venture creation process than are men. This suggests that for women, all types of social support are important in their venture creation processes.
\end{abstract}

Keywords: nascent women entrepreneurs, start-up activities, social context, university support, family support, Global University Entrepreneurial Spirit Students' Survey (GUESSS).

JEL: A22, D83, L26.

This research has been conducted with financial support from Russian Science Foundation (project No. 1918-00081).

Postal Addresses: ${ }^{a} 175$, Forest Street, Management Department, Bentley University, Waltham, MA 024524705, USA; ${ }^{\mathrm{b}}$ 3, Volkhovskiy per., Graduate School of Management, St. Petersburg State University, St. Petersburg, 199004, Russia; ${ }^{\mathrm{c}}$ 3, Kantemirovskaya ul., Department of Management, National Research University Higher School of Economics, St. Petersburg, 194100, Russia.

(ㄴ. F. Edelman, T. Manolova, G. Shirokova, T. Tsukanova, 2020

https://doi.org/10.21638/spbu18.2020.201

PЖM 18 (2): 127-154 (2020) 


\section{INTRODUCTION}

Context is now recognized as a crucial factor in explaining the phenomenon of interest in our paper, entrepreneurial activity [McKeever, Jack, Anderson, 2015; Shepherd et al., 2019; Welter, 2011; Zazdravnykh, 2019]. Context is defined as "the circumstances, conditions, situations, or environments that are external to the respective phenomenon and enable or constrain it" [Welter, 2011, p. 167]. Entrepreneurial activity can be examined in multiple contexts such as the business context (e.g., industry or market), the spatial context (e.g., country, community, district, or cluster), institutional (e.g., political system or cultural milieu), or social (e.g., different types of social networks). All of these different factors existing in the external environment provide situational opportunities and constraints that affect behavior. In this paper, we focus, in particular, on the social context in which young aspiring entrepreneurs (university students, in our case) engage in start-up activities.

According to the social context view, entrepreneurs are embedded in a social context, and that context facilitates or restricts their actions [Aldrich, Zimmer, 1986; McKeever, Jack, Anderson, 2015]. One important aspect of the entrepreneurial social context is the entrepreneur's social network. If we conceive of the entrepreneur as an organizer and coordinator of resources [Hébert, Link, 1989], then social networks help entrepreneurs to garner the knowledge and resources that are needed to start a new firm. Young people have little, if any, business knowledge, few social relations, and little experience in how to make sense of the entrepreneurial process. They rely on their family and on the knowledge and contacts that they gain during their university experience for access to start-up resources [Dana et al., 2020; Nielsen, Lassen, 2012; Shirokova, Bogatyreva, Galkina, 2014]. Specifically, we look at the influence of the student's family and their university. We argue that students are embedded in social networks comprised of both family members and university connections, and that these networks allow access to critical resources that are needed for students to engage in start-up activities.

In addition, we are particularly interested in the gendered effect of the social context for start-up activity. Prior research has suggested that women are disadvantaged with respect to the social support for their entrepreneurial aspirations, as their networks tend to be smaller and comprised predominantly of strong ties [Aldrich, Reese, Dubini, 1989; Greve, Salaff, 2003; Renzulli, Aldrich, Moody, 2000]. However, in this paper, we raise a different question. Specifically we ask: Who makes better use of social networks for their nascent entrepreneurial activity, young men or young women?

We test our hypotheses using data from the 2011 "Global University Entrepreneurial Spirit Students' Survey” (GUESSS), selecting only those respondents who were actually involved in the process of starting up a business, to a usable sample of 16744 students at 246 universities in 17 countries. The GUESSS project is a panel study of university students, which records founding intentions and activities on a biannual basis.

Our study makes three contributions. First, we contribute to the nascent entrepreneurship literature [Davidsson, 2006; Gartner, Carter, Reynolds, 2004; Reynolds, 2010] by documenting the role played by social context, in the form of personal and social networks, in shaping entrepreneurial actions. Prior research has focused on the social structure of founding teams [Ruef, Aldrich, Carter, 2003] or the effect of different types of social networks on the early success of entrepreneurial initiatives [Davidsson, Honig, 2003; Rasmussen, Mosey, Wright, 2015]. In contrast, we examine how social context, in the form of different types of social ties, affects the nascent entrepreneurs' progress through the venturing process.

Second, we contribute to the literature on the gendered aspects of new venture creation. More specifically, our study documents how the gendered differences of, in our case, family connections, and university networks, influence the scope of start-up activities. Our

РЖM 18 (2): 127-154 (2020) 
finding that women make better use of both strong-tie family connections and weaker tie university connections suggests that previous gendered perspectives, which focused on women's strong-tie networks [Brush, 1992], need to be updated and extended to include all different types of network connections.

Third, we make an empirical contribution by documenting the start-up initiatives of university students. Extensive prior research has explored the entrepreneurial intentions of university students [Autio et al., 2001; Bogatyreva et al., 2019; Carey, Flanagan, Palmer, 2010; Kolvereid, 1996; Krueger, Reilly, Carsrud, 2000; Weiss, Anisimova, Shirokova, 2019; Wegner et al., 2020; Zellweger, Sieger, Halter, 2011], but the actual realization of these intentions is relatively less well studied. On the following pages, we present our theory and hypotheses, followed by the empirical analysis, our findings and discussion and the overall conclusions.

\section{THEORY AND HYPOTHESES}

\subsection{The nascent entrepreneur and start-up activities}

Nascent entrepreneurs are those individuals who are in the process of starting a new venture [Delmar, Davidsson, 2000; Reynolds, Storey, Westhead, 1994]. Start-up activities are the events and behaviors of individuals who are engaged in the process of starting a new venture [Carter, Gartner, Shaver, 2004; Gartner, Carter, Reynolds, 2004; Reynolds, Miller, 1992; Edelman et al., 2016] and constitute the "micro-foundations of entrepreneurial action" [Shepherd, 2015, p. 490]. These activities, such as formulating a business plan, identifying a market opportunity, or looking for potential partners, are the fundamentals of new venture creation.

While a number of studies have looked at the effects of engaging in start-up activities on organizational emergence or first sales [Brush, Manolova, Edelman, 2008; Lichtenstein et al., 2007], less research has looked at the antecedents to engaging in the start-up process. P. Davidsson and B. Honig used the number of gestation activities undertaken as one of their dependent variables when they explored the human and social capital of nascent entrepreneurs [Davidsson, Honig, 2003]. M. Samuelsson and P. Davidsson used progress in the venturing process, which was measured as a summation of gestation activities, as their outcome variable [Samuelsson, Davidsson, 2009]. More recently, Edelman and coauthors looked at family social support, finding that access to families' social networks had a positive effect on the scope of start-up activities; whereas family's financial support had a negative effect [Edelman et al., 2016].

In sum, there is a diverse body of research that has used gestation activities as an outcome variable. Some studies have focused on individual or small sets of gestation activities, while other studies summed the activities to illustrate overall progress in the venturing process. In our inquiry, we also use the scope of start-up activities as evidence of progress through the venturing process, specifically focusing on activities such as serious thought given to the start-up, talking to customers, developing a model, looking for potential partners, purchasing or leasing a capital asset, promoting the good or service, completing a business plan, seeking external funding, and deciding on date of founding.

\subsection{Social networks: The social context for nascent entrepreneurship}

Nascent entrepreneurs must construct networks of social relationships as they engage in the process of obtaining resources for their fledging firms [Aldrich, 1989]. Social networks allow entrepreneurs to gain access to opportunities, information, and resources, save time, and tap into advice and moral support that may otherwise be unavailable. Student entrepreneurs, the population of interest to our study, are likewise embedded in networks of social relationships, some of which are 
strong personal relations such as ties to family, while others are weaker such as ties to occasional friends and other acquaintances.

\subsection{Strong ties: Social networks and family support}

Strong ties tend to be long-standing relationships based on frequent contacts such as those existing among family members or close friends [Coleman, 1988]. They offer a number of important benefits to the nascent entrepreneur. Information gained through strong ties tends to be more trustworthy, detailed, and accurate, and so in economic terms is considered more reliable [Granovetter, 1985]. Strong ties are long in duration and are based on the principle of implicit reciprocity. Reciprocity is the degree to which individuals provide comparable supportive actions to each other [Gouldner, 1960]. Researchers have shown that the norm of reciprocity is partly responsible for the higher levels of social support found in dense networks (see [Haines, Hurlbert, 1992; Wellman, Wortley, 1990]). Strong ties are also quick and easy to access, which, combined with their high level of trustworthiness and reliability, increases the efficiency of social exchange.

The long-term nature, implicit reciprocity, and frequency of contact make family ties a classic example of strong ties. Young entrepreneurs use their parents' social networks to gain information and access to new market opportunities [Sørensen, 2007]. Children may access the parents' contacts with suppliers, business partners, and customers, to maintain progress in the nascent venturing process [Laspita et al., 2012].

Strong ties are found in dense social networks. Authors [Aldrich, Elam, Reese, 1997, p. 6] refer to these ties as core or inner circle relationships, and go on to suggest that they form a "bulwark against an owner's being exploited by people out only for short-term gain”. P. DiMaggio and H. Louch suggest that due to reciprocity norms, entrepreneurs may find a more friendly reception to their calls for resources from their strong tie connections [DiMaggio, Louch, 1998]. Therefore, resource constrained entrepreneurs need to rely on the norms of reciprocity that are found in strong family networks to access critical resources. Formally,

Hypothesis 1. The greater the family support, in the form of social contacts, the greater the young nascent entrepreneur's progress through the venturing process.

\subsection{Weak ties: Social networks and the university environment}

While strong ties are based on frequent contact, trust, and norms of reciprocity, they have some drawbacks as well. Strong ties, which are long in duration, tend to develop between people with similar social attributes, and so can provide redundant information [Burt, 1992; 2004]. In contrast, weak ties are comprised of relationships that are much shorter in duration, are less reliable, involve a lower frequency of contact, and have a much lower expectation for reciprocity. While strong ties are vital for securing critical resources and emotional support, weak ties are more efficient for knowledge acquisition, because the diversity of contacts is less likely to provide redundant information. Weak ties aid in resource acquisition in that they help to bridge otherwise disconnected groups and individuals in an organization [Granovetter, 1973].

Weaker, nonfamily ties have a number of advantages for the nascent entrepreneur. Nonfamily members are better positioned to provide informed advice and candid feedback. Unlike situations in which family may not be willing to dispense impartial assessments, nonfamily relations do not face such constraints and thus are able to provide advice with greater clarity and honesty. This can translate into valuable feedback as aspiring owners wrestle with business ideas or working prototypes. In addition, nonfamily members can prevent business owners from making costly mistakes early in the start-up process. Consider the considerable benefits of informational sup- 
port from an impartial nonfamily member when the fledgling entrepreneur is negotiating an initial sales contract or finalizing details of securing physical space for the business.

The university context can be a source of valuable social contacts for the aspiring student-entrepreneur. Universities contribute to the level of engagement in entrepreneurship and to the student entrepreneur's overall progress through the venturing process [Meoli et al., 2020; Morris, Shirokova, Tsukanova, 2017]. In addition to offering entrepreneurship courses and programs, universities facilitate entrepreneurial activity by organizing networking events, business plan competitions, and providing mentoring and sometimes even seed funding.

Students who access university resources meet fellow students with similar entrepreneurial experiences. This environment not only can give rise to a sense of belonging [Anderson, Drakopoulou-Dodd, Jack, 2012; McKeever, Jack, Anderson, 2015], but can also provide valuable ties into other, more distant social networks. For example, in a recent study of the university and regional influences on student entrepreneurial activity, authors [Bergmann, Hundt, Sternberg, 2016] documented that, after controlling for individual characteristics, the prevalence of fellow students who had attended entrepreneurship education has a positive effect on the nascent entrepreneurship of students. Hence, the entrepreneurial impact of universities is a function of the social resources it can supply to the nascent entrepreneur. Formally,

Hypothesis 2. The greater the support for starting a new venture at the university level, the greater the young nascent entrepreneur's progress through the venturing process.

\subsection{The moderating role of gender}

The role of the family and university context may be strongly affected by the gender ${ }^{1}$ of

1 We are cognizant of the important distinction between the biological sex of the individual and the young nascent entrepreneur. Women entrepreneurs are embedded in different personal and social networks than are men [Brush, 1992; Granovetter, 1985]. Evidence suggests that women inhabit a "female world" that only partially overlaps with the "male world" [Bernard, 1981]. Other research posits that women have different patterns of childhood socialization [Gilligan, 1982] and view social relations differently than men, leading to different networking behaviors [Aldrich, 1989].

During the venture creation process, women rely on strong ties that are expressive and characterized by emotional intensity, mutual confiding, and intimacy, such as those found in the family [Renzulli, Aldrich, Moody, 2000]. Research into the gendered differences in entrepreneurial finance suggests that women entrepreneurs were more likely to obtain money from personal sources, such as family and friends, to finance their businesses than were men [Carter et al., 2003]. Women are more likely than men to seek family approval for their entrepreneurial initiatives [Aldrich, 1989], and in traditional societies and patriarchal families, they are strongly expected and often required to do so [Al-Dajani, Marlow, 2010; McIntosh, Islam, 2010]. Thus, an introduction into the family's social network is a stamp of approval that bestows legitimacy on the young woman's entrepreneurial initiative and facilitates the completion of other start-up activities. Formally,

Hypothesis $3 a$. The effect of family social support on the nascent entrepreneurs' progress through the venturing process is stronger for women than for men.

Homophily is the principle that a contact between similar people occurs at a higher rate than among dissimilar people. It is a basic organizing principle and can be found in almost every social interaction such as marriage, friendship, work, advice support,

their socially constructed gender. Our survey only collected data on the self-reported biological sex of the respondent; hence we use this variable as a measure of the respondent's gender. 
information transfer, and exchange. The idea is that generally, people only have significant contact with others who are like themselves [McPherson, Smith-Lovin, Cook, 2001]. Interpersonal similarity increases ease of communication, and fosters relationships of trust and reciprocity [Kanter, 1977; Lincoln, Miller, 1979].

When controlling for family effects, researchers have found significant evidence of sex differences in networks [Brass, 1985]. There are two theoretical perspectives that explain this finding. The first emphasizes individual preferences for relationships with similar others [Brass, 1985; Lincoln, Miller, 1979; Marsden, 1988], while the other offers a more structural explanation, positing that the availability of contact precedes and hence limits individual network composition preferences. These two perspectives correspond well with arguments that differentiate between choice homophily, which results from individual preferences and induced homophily, which is the result of availability constraints [Ibarra, 1993].

Empirical research in the entrepreneurship literature confirms that men do not include women in their business advisor networks. In a study of close ties in five industrial nations, authors [Aldrich, Sakano, 1995] found that only $10 \%$ of the people mentioned by men, as those who they relied upon for advice and assistance, were women. This is contrast with women, where $40 \%$ of their advice networks were other women. In sum, men rely on other men for business advice, where women rely more on mixed gender networks.

In addition to induced homophily, there are other differences in the way men and women structure their weak-tie networks. Men tend to see situations in terms of what they may gain from them and are willing to subordinate affective considerations to ones of effectiveness [Aldrich, 1989]. Not surprisingly, men are found to be more likely to spend more time developing and maintaining their networks [Cromie, Birley, 1990] and more likely to form calculative than identity- based networks [Hite, Hesterly, 2001]. Identitybased networks are egocentric with a high proportion of ties, and where some type of personal or social identification with the other actor motivates or influences economic actions. However, in calculative networks the potential purposes and functions of the network tie become a more predominant theme than the identity of the tie, so that the focal actor's ties are primarily motivated by expected economic benefits [Hite, Hesterly, 2001, p. 278]. For example, in a study of the weak-tie networks of American entrepreneurs and salaried managers, it is documented that entrepreneurs' weak-tie networks efforts were less than in the networks of managers, with female entrepreneurs engaging in weak-tie networking less than salaried male managers do [Katz, Williams, 1997].

Therefore, given the importance of networks in the start-up process [Aldrich, Sakano, 1999], coupled with contention, "similarity breeds connection" [McPherson, Smith-Lovin, Cook, 2001, p. 451], we suggest that the effects of university support will be weaker for female student entrepreneurs than for men. Formally,

Hypothesis $3 b$. The effect of university support on the nascent entrepreneurs' progress through the venturing process is weaker for women than for men.

\section{METHODS}

\subsection{Data collection}

We used data from the 2011 installment of the "Global University Entrepreneurial Spirit Students' Survey" (GUESSS) ${ }^{2}$ which was designed to examine entrepreneurial intentions and activities of students in higher education (for more details see [Sieger, Fueglistaller, Zellweger, 2011]). Thus, the study population

\footnotetext{
${ }^{2}$ We used the 2011 data because the key constructs (and scales) of our study were included only in 2011 round of data collection and are not available from more recent installments (2014, 2016 and 2018).
} 
is homogeneous in terms of age and qualifications. Participating universities distributed a link to an online questionnaire and controlled the data collection process. The original survey instrument was developed in English and German, using bilingual experts and following translation and back-translation procedures. For non-English speaking countries, the country teams were responsible for translating the questionnaire in their own languages ${ }^{3}$.

The 2011 GUESSS survey comprised 93265 responses of students from 489 universities in 26 countries. The response rate was $6.3 \%$ (in total, 1374678 students were addressed). We selected only those students who were "intentional founders", i.e. in the process of starting a new venture and between 18 and 34-years old. In addition, we excluded "study abroad" program students and the cases where there were fewer than four students per university and fewer than four universities per country to provide within-country and within-university variability. Our final sample consists of 16744 students at 246 universities in 17 countries (Argentina, Belgium, Brazil, Chile, China, Finland, France, Germany, Hungary, Ireland, Japan, the Netherlands, Romania, Russia, Singapore, South Africa, and the United Kingdom).

The average participant of the 2011 GUESSS study was relatively young (23.72 years old). Within our sample, $84 \%$ of students were undergraduate students, $40.07 \%$ were studying Business and Economics, $72.75 \%$ had taken at least one entrepreneurship course and $54.27 \%$ had at least one parent who at the time of survey was self-employed or had been self-employed at some point in the past. Women comprised $45.91 \%$ of the sample.

\subsection{Measures}

Dependent variable. The dependent variable of our study was a tally of nine self-reported binary variables tracking different start-up

\footnotetext{
${ }^{3}$ More information about the survey instrument translation procedure is available in [Laspita et al., 2012].
}

activities, such as "thought of first business ideas", "formulated business plan", "identified market opportunity", "looked for potential partners", "purchased equipment", "worked on product development", "discussed with potential customers", "asked financial institutions for funding", and "decided on date of founding" [Carter, Gartner, Shaver, 2004]. The average nascent entrepreneur in our sample had undertaken 1.96 start-up activities at the time of the survey.

Independent variables. We measured the perceived level of family support with two items where the students were asked to indicate to what extent they agreed with the statements: "My parents/family provide me with contacts to people that might help me with pursuing an entrepreneurial career; My parents/family introduce me to business networks, providing contacts to potential business partners and/or customers", on a sevenpoint Likert-type scale ranging from " 1 " "not at all" to "7" - "very much' (Cronbach's alpha $=0.9076$ ).

To measure the university support, we tracked whether or not the responded participated in events such as: 1) workshops/ networking with experienced entrepreneurs; 2) contact platforms with potential investors; 3) business plant contests/workshops; 4) mentoring and coaching programs for entrepreneurs; 5) contact point for entrepreneurial issues. Each activity represented a binary response ("1" — "yes" and " 0 " — "no"). We tallied these co-curricular activities, with a range of $0-5$.

Moderator. Our moderator, gender, was coded as a dummy variable with " 1 " for female students, and " 0 " - for male students.

Control variables. We used a total of 16 control variables to account for other factors influencing a student's progress through the venturing process. We controlled for students' age (the older the student, the more likely $\mathrm{s} /$ he has already entered the venturing process), the study level (coded "1" - for bachelor level, "0" - for other study programs), the field of study (four categories: "Business \& Economics", "Natural Science", "Social Science", 
and "Other"), and the marital status of students (three categories: "Single", "Married", or "Divorced"). To account for self-employed parents ("family background"), we used a corresponding dummy (coded as " 1 " if the parents had ever been self-employed or they were self-employed at the moment of survey, and "0", otherwise). Since entrepreneurial knowledge can be a driver of the individual's decision to embark on an entrepreneurial career, we used a dummy variable, entrepreneurial courses, indicating whether the individual had attended any entrepreneurship course at the university (coded as " 1 " if a student attended at least one course on entrepreneurship, and "0", otherwise). We also controlled for other individual-level characteristics, which can potentially influence entrepreneurial behavior including previous experience relevant to the company to be founded (coded as " 1 " for "yes", and " 0 ", otherwise), level of commitment (self-reported percent of weekly working time a student planned to invest in his/her company) and the number of partners participating in the new venture (self-reported count). We also included the family cohesiveness as a measure of the degree of connectedness and emotional bonding within the family [Laspita et al., 2012; Shagalkina et al., 2019]. Students were asked to indicate their level of agreement with four statements: "Family togetherness is important; Family members feel very close; When family gets together, everyone is present"; "Family members ask each other for help". Each statement was measured using a 7-point Likert-type scale (from "1" - "completely disagree" to "7" — “completely agree"), Cronbach's alpha 0.8417 .

To account for country-specific differences in our 17-country sample, we added several country-level control variables for GDP per capita (log-transformed) ${ }^{4}$, Nascent Entrepreneurship Rate (NEA), and the perception of entrepreneurship as a good career

\footnotetext{
4 The World Bank. URL: http://data.worldbank. org/indicator/NY.GDP.PCAP.CD (accessed: 25.06. 2020)
}

choice $^{5}$. NEA reflects the nascent entrepreneurial activity in a country, i.e. only those starting new companies less than 3 months old. The perception of entrepreneurship as a good career choice shows the societal beliefs about entrepreneurship and indicates the number of people who do agree that starting a business is a good career choice.

To account for the individual's subjective perception of the external environment we included three additional controls, "the access to financial capital" (debt and equity capital), "state laws" (rules and regulations), and "general economic environment". Students were asked to indicate to what extent these issues represented a barrier to founding a company, using a 7-point Likert-type scale (from " 1 " "not at al" to "7" - "very much"). The answers were reverse coded to indicate the perceived level of environmental favorability. Our country-level measures are thus a combination of objective and perceptual measures and control for important aspects of the economic, spatial, and institutional context for entrepreneurship.

Common method bias is not a major concern in our data. The data collection process was anonymous and the survey participants were not given any pressure toward socially desirable answers. In addition, the Harman single-factor tests [Podsakoff et al., 2003] confirmed that there was no one single factor accounting for data variance. Furthermore, there is evidence that common method bias usually deflates the interaction effects [Siemsen, Roth, Oliveira, 2010]. In our case we found significant interaction effects and this can be considered as a signal that common method bias did not cause a serious problem. We also used the standardized variables [Cohen et al., 2003] to minimize the correlations between the main effects and the interaction terms.

The descriptive statistics and correlations are presented in Tables 1 and 2, respectively. One can notice that all correlations between

5 Global Entrepreneurship Monitor 2011. URL: http://www.gemconsortium.org/report (accessed: 25.06.2020) 
variables are modest and range from -0.2884 to 0.2989 . We examined the multicollinearity issue by calculating the variance inflation factors. The results showed that all values were $<1.46$, well below the acceptable threshold [Hair et al., 1998].

\section{Descriptive statistics}

\begin{tabular}{|c|c|c|c|c|c|}
\hline Variable & Mean & Std. Dev. & Min & $\operatorname{Max}$ & $\%$ \\
\hline \multicolumn{6}{|c|}{ Dependent variable } \\
\hline Progress of venturing process & 1.96 & 1.66 & 0 & 9 & - \\
\hline \multicolumn{6}{|c|}{ Control variables } \\
\hline Age & 23.72 & 3.63 & 18 & 34 & - \\
\hline Study level (bachelor) & 0.84 & 0.36 & 0 & 1 & 84.19 \\
\hline $\begin{array}{l}\text { Field of study (business \& } \\
\text { Economics) }\end{array}$ & - & - & - & - & 40.07 \\
\hline Field of study (natural science) & - & - & - & - & 28.75 \\
\hline Field of study (social science) & - & - & - & - & 7.71 \\
\hline Field of study (other) & - & - & - & - & 23.47 \\
\hline Family background (yes) & 0.54 & 0.50 & 0 & 1 & \\
\hline Entrepreneurship courses (yes) & 0.73 & 0.45 & 0 & 1 & 72.75 \\
\hline Previous experience (yes) & 0.42 & 0.49 & 0 & 1 & 42.23 \\
\hline Commitment & 51.92 & 28.14 & 0 & 100 & - \\
\hline Partners & 1.03 & 0.97 & 0 & 4 & - \\
\hline Cohesiveness & 3.33 & 0.75 & 0.60 & 4.17 & - \\
\hline Status (single) & - & - & - & - & 89.93 \\
\hline Status (married) & - & - & - & - & 9.48 \\
\hline Status (divorced) & - & - & - & - & 0.59 \\
\hline GDP (log) & 9.97 & 0.68 & 8.60 & 10.88 & - \\
\hline NEA & 4.6 & 2.29 & 2.4 & 14.6 & - \\
\hline $\begin{array}{l}\text { Entrepreneurship as a good } \\
\text { career choice (GEM) }\end{array}$ & 73.50 & 14.26 & 26 & 86.3 & - \\
\hline Access to financial capital & 3.08 & 1.78 & 1 & 7 & - \\
\hline Laws & 4.18 & 1.83 & 1 & 7 & - \\
\hline Economic environment & 3.9 & 1.73 & 1 & 7 & - \\
\hline \multicolumn{6}{|c|}{ Moderating variable } \\
\hline Gender (female) & 0.46 & 0.50 & 0 & 1 & 45.91 \\
\hline \multicolumn{6}{|c|}{ Independent variables } \\
\hline Family social support & 3.38 & 1.87 & 0.99 & 6.96 & - \\
\hline University support & 0.89 & 1.29 & 0 & 5 & - \\
\hline
\end{tabular}

Note: $N=16744$. 
Correlation

\begin{tabular}{|c|c|c|c|c|c|c|c|c|}
\hline$N$ & Variable & 1 & 2 & 3 & 4 & 5 & 6 & 7 \\
\hline 1 & Progress in venturing process & 1.00 & & & & & & \\
\hline 2 & Age & $0.13 *$ & 1.00 & & & & & \\
\hline 3 & Study level (bachelor) & $-0.04 *$ & $-0.25 *$ & 1.00 & & & & \\
\hline 4 & Family background & $0.08 *$ & -0.003 & $0.05 *$ & 1.00 & & & \\
\hline 5 & Entrepreneurship courses & $0.12 \%$ & 0.005 & $-0.02 \%$ & $0.03 *$ & 1.00 & & \\
\hline 6 & Previous experience & $0.22 \%$ & $0.27 *$ & $-0.05 *$ & $0.07 *$ & $0.04 *$ & 1.00 & \\
\hline 7 & Commitment & $0.07 *$ & $0.03 *$ & $0.03 *$ & $0.02 \%$ & $0.02 *$ & $0.07 *$ & 1.00 \\
\hline 8 & Partners & $0.12 *$ & $-0.08 *$ & -0.00 & $-0.02 \%$ & $0.04 *$ & $-0.05 *$ & 0.006 \\
\hline 9 & Cohesiveness & $-0.02 \%$ & $-0.04 *$ & $0.04 \%$ & $0.04 \%$ & $0.04 *$ & $-0.04 \%$ & $0.04 \%$ \\
\hline 10 & GDP $(\log )$ & $-0.03 *$ & $0.02 \%$ & $-0.29 *$ & $-0.14 \%$ & $-0.07 *$ & -0.001 & $-0.13 \%$ \\
\hline 11 & NEA & 0.004 & $-0.05^{*}$ & $0.06 *$ & $0.12 *$ & $0.03 *$ & $-0.04 *$ & -0.005 \\
\hline 12 & $\begin{array}{l}\text { Entrepreneurship as a good career } \\
\text { choice (GEM) }\end{array}$ & $0.07 *$ & $0.07 *$ & $0.17 *$ & $0.15 *$ & $0.05 *$ & $0.06 *$ & 0.006 \\
\hline 13 & Access to financial capital & $0.07 *$ & 0.005 & $-0.03 *$ & $0.06 *$ & 0.0007 & $0.03 \%$ & -0.01 \\
\hline 14 & Laws & $0.03 *$ & $-0.02 \%$ & -0.02 & 0.006 & -0.003 & 0.003 & $0.03 *$ \\
\hline 15 & Economic environment & $0.12 *$ & $0.02 \%$ & $-0.04 \%$ & $0.03 \%$ & -0.006 & $0.05 *$ & $0.02 \%$ \\
\hline 16 & Gender & $-0.17 *$ & $-0.08 *$ & $0.05 \%$ & -0.002 & -0.01 & $-0.09 *$ & -0.008 \\
\hline 17 & Family social support & $0.02 *$ & $-0.19 *$ & $0.07 *$ & $0.20 *$ & $0.06 *$ & $-0.03 \%$ & $0.03 *$ \\
\hline 18 & University support & $0.14 *$ & $-0.05^{*}$ & $-0.02 *$ & $0.05 *$ & $0.30 *$ & $0.04 \%$ & 0.01 \\
\hline
\end{tabular}

Not e: * indicates significance at the $5 \%$ level or better.

\section{RESULTS}

Since our dependent variable is a count, we used a Poisson regression model to test the effects of our independent variables. To account for the nested structure of our data we employed the hierarchical multi-level mixedeffect model for the Poisson distribution, utilizing the xtmepoisson procedure in Stata. Table 3 displays the results of our analysis.

We first entered the control variables including the moderator (Model 1). Among the control variables, age $(\beta=0.018$, $p<0.001$ ) was positively and significantly associated with the scope of start-up activities, as was the entrepreneurial family background $(\beta=0.086, p<0.001)$, taking at least one entrepreneurship course $(\beta=0.167, p<0.01)$, previous work experience $(\beta=0.297, p<0.01)$, commitment $(\beta=0.002, p<0.001)$, number of partners $(\beta=0.102, p<0.001)$, as well as the perceived munificence of the environment including favorable access to finance $(\beta=0.017$, $p<0.001$ ) and the general economic environment $(\beta=0.041, p<0.001)$. Young women were engaged in significantly fewer start-up activities compared to their male counterparts $(\beta=-0.232, p<0.001)$.

In the next step, we added our main independent variables: family support (Model 2) and university support (Model 3). Finally, we added the interaction effects between family support and gender (Model 4), the university support and gender (Model 5). All these models improved in comparison 
matrix

\begin{tabular}{c|c|c|c|c|c|c|c|c|c|c}
\hline 8 & 9 & 10 & 11 & 12 & 13 & 14 & 15 & 16 & 17 & 18 \\
\hline & & & & & & & & & & \\
\hline & & & & & & & & & & \\
\hline & & & & & & & & & & \\
\hline & & & & & & & & & & \\
\hline & & & & & & & & & & \\
\hline & & & & & & & & & & \\
\hline 1.00 & & & & & & & & & & \\
\hline $0.03 *$ & 1.00 & & & & & & & & & \\
\hline$-0.07 *$ & $-0.16 *$ & 1.00 & & & & & & & & \\
\hline $0.10 *$ & $0.09 *$ & $-0.24 *$ & 1.00 & & & & & & & \\
\hline$-0.04 *$ & -0.005 & $-0.37 *$ & $0.08 *$ & 1.00 & & & & & & \\
\hline$-0.04 *$ & $-0.03 *$ & $0.07 *$ & $-0.02 *$ & $0.06 *$ & 1.00 & & & & & \\
\hline$-0.03 *$ & $-0.02 *$ & $0.06 *$ & $0.05 *$ & $-0.02 *$ & $0.28 *$ & 1.00 & & & & \\
\hline$-0.02 *$ & $-0.06 *$ & $0.09 *$ & $-0.03 *$ & $0.07 *$ & $0.27 *$ & $0.30 *$ & 1.00 & & & \\
\hline$-0.08 *$ & $0.11 *$ & $-0.08 *$ & -0.009 & 0.008 & $-0.05 *$ & $0.04 *$ & $-0.07 *$ & 1.00 & & \\
\hline $0.03 *$ & $0.28 *$ & $-0.07 *$ & $0.12 *$ & $0.05 *$ & $0.07 *$ & $-0.07 *$ & $-0.04 *$ & $0.02 *$ & 1.00 & \\
\hline $0.04 *$ & $0.06 *$ & $0.02 *$ & 0.006 & $0.09 *$ & $0.02 *$ & $-0.04 *$ & 0.004 & $-0.03 *$ & $0.15 *$ & 1.00 \\
\hline
\end{tabular}

with the main-effect-only model as shown by their AIC and BIC values.

With regard to our main-effect research hypotheses, we find a significant positive relationship (Model 2, $\beta=0.012, p<0.001$ ) between family support and the progress through the venturing process. Thus, Hypothesis 1 is supported. Moreover, we find a significant positive relationship (Model 3, $\beta$ $=0.055, p<0.001$ ) between university support and the venturing progress. The Hypothesis 2 is also supported.

The main purpose of our study was to explore whether gender can explain why the family and university have a different effect on the venturing process. The first interaction effect between family support and gender is significant and positive (Model 4, $\beta=0.031, p<0.001$ ), indicating support for Hypothesis $3 \mathrm{a}$. When the interaction effect is added, the direct effect of family support becomes insignificant and takes the opposite sign, suggesting a potential crossover interaction. Indeed, the association between family support and the venturing progress is negative for men but positive for women. The gendered effect of family social networks is visualized in Figure $\mathbf{1}^{6}$. It can be noted that the line for man slopes slightly down, while for women it goes up. In other words, the graph highlights that the impact

${ }^{6}$ For Figures 1 and 2: the margins command in Stata cannot compute predicted values for models that have both fixed and random components. Hence, we derived the predicted probabilities from just the fixed part of the model. 
Table 3

HLM estimates of the progress in venturing process

\begin{tabular}{|c|c|c|c|c|c|}
\hline Variable & Model 1 & Model 2 & Model 3 & Model 4 & Model 5 \\
\hline \multicolumn{6}{|c|}{ Control variables } \\
\hline Age & $\begin{array}{c}0.018 * * * \% \\
(0.002)\end{array}$ & $\begin{array}{l}0.019 * * * \\
(0.002)\end{array}$ & $\begin{array}{l}0.018 * * * \\
(0.002)\end{array}$ & $\begin{array}{l}0.019 * * * \\
(0.002)\end{array}$ & $\begin{array}{l}0.019 * * * \\
(0.002)\end{array}$ \\
\hline Study level (bachelor) & $\begin{array}{l}-0.022 \\
(0.018)\end{array}$ & $\begin{array}{l}-0.023 \\
(0.018)\end{array}$ & $\begin{array}{l}-0.022 \\
(0.018)\end{array}$ & $\begin{array}{l}-0.020 \\
(0.018)\end{array}$ & $\begin{array}{l}-0.019 \\
(0.018)\end{array}$ \\
\hline $\begin{array}{l}\text { Field of study (natural } \\
\text { science) } \dagger\end{array}$ & $\begin{array}{c}0.007 \\
(0.015)\end{array}$ & $\begin{array}{c}0.008 \\
(0.015)\end{array}$ & $\begin{array}{c}0.007 \\
(0.015)\end{array}$ & $\begin{array}{c}0.008 \\
(0.015)\end{array}$ & $\begin{array}{c}0.010 \\
(0.015)\end{array}$ \\
\hline $\begin{array}{l}\text { Field of study (social } \\
\text { science) }\end{array}$ & $\begin{array}{l}-0.031 \\
(0.025)\end{array}$ & $\begin{array}{l}-0.030 \\
(0.025)\end{array}$ & $\begin{array}{l}-0.031 \\
(0.025)\end{array}$ & $\begin{array}{l}-0.025 \\
(0.025)\end{array}$ & $\begin{array}{l}-0.025 \\
(0.025)\end{array}$ \\
\hline Field of study (other) & $\begin{array}{l}-0.004 \\
(0.015)\end{array}$ & $\begin{array}{l}-0.004 \\
(0.015)\end{array}$ & $\begin{array}{l}-0.004 \\
(0.015)\end{array}$ & $\begin{array}{l}-0.000 \\
(0.015)\end{array}$ & $\begin{array}{l}-0.001 \\
(0.015)\end{array}$ \\
\hline Family background & $\begin{array}{c}0.086 * * * \\
(0.012)\end{array}$ & $\begin{array}{l}0.079 * * * \\
(0.012)\end{array}$ & $\begin{array}{l}0.086 * * * \\
(0.012)\end{array}$ & $\begin{array}{c}0.076 * * * \\
(0.012)\end{array}$ & $\begin{array}{l}0.077 * * * \\
(0.012)\end{array}$ \\
\hline Entrepreneurship courses & $\begin{array}{c}0.167 * * * \\
(0.014)\end{array}$ & $\begin{array}{l}0.166 * * * \\
(0.014)\end{array}$ & $\begin{array}{c}0.167 * * \% \\
(0.014)\end{array}$ & $\begin{array}{c}0.119 * * * \\
(0.014)\end{array}$ & $\begin{array}{l}0.120 * * * \\
(0.014)\end{array}$ \\
\hline Previous experience & $\begin{array}{c}0.297 * * * \\
(0.012)\end{array}$ & $\begin{array}{c}0.296 * * * \\
(0.012)\end{array}$ & $\begin{array}{c}0.297 * * * \\
(0.012)\end{array}$ & $\begin{array}{c}0.290 * * * \\
(0.012)\end{array}$ & $\begin{array}{c}0.291 * * * \\
(0.012)\end{array}$ \\
\hline Commitment & $\begin{array}{c}0.002 * * * \\
(0.000)\end{array}$ & $\begin{array}{c}0.002 * * * \\
(0.000)\end{array}$ & $\begin{array}{c}0.002 * * * \\
(0.000)\end{array}$ & $\begin{array}{c}0.001 * * * \\
(0.000)\end{array}$ & $\begin{array}{c}0.001 * * * \\
(0.000)\end{array}$ \\
\hline Partners & $\begin{array}{c}0.102 * * * \\
(0.006)\end{array}$ & $\begin{array}{c}0.102 * * * \\
(0.006)\end{array}$ & $\begin{array}{c}0.102 * * * \\
(0.006)\end{array}$ & $\begin{array}{c}0.100 * * * \\
(0.006)\end{array}$ & $\begin{array}{c}0.100 * \% * \\
(0.006)\end{array}$ \\
\hline Cohesiveness & $\begin{array}{l}-0.012 \\
(0.008)\end{array}$ & $\begin{array}{c}-0.020 \% \\
(0.008)\end{array}$ & $\begin{array}{l}-0.012 \\
(0.008)\end{array}$ & $\begin{array}{c}-0.024 * \% \\
(0.008)\end{array}$ & $\begin{array}{c}-0.024 * \% \\
(0.008)\end{array}$ \\
\hline Status (married) $\dagger \dagger$ & $\begin{array}{c}0.013 \\
(0.020)\end{array}$ & $\begin{array}{c}0.013 \\
(0.020)\end{array}$ & $\begin{array}{c}0.013 \\
(0.020)\end{array}$ & $\begin{array}{c}0.016 \\
(0.020)\end{array}$ & $\begin{array}{c}0.015 \\
(0.020)\end{array}$ \\
\hline Status (divorced) & $\begin{array}{c}0.053 \\
(0.068)\end{array}$ & $\begin{array}{c}0.058 \\
(0.068)\end{array}$ & $\begin{array}{c}0.053 \\
(0.068)\end{array}$ & $\begin{array}{c}0.058 \\
(0.068)\end{array}$ & $\begin{array}{c}0.056 \\
(0.068)\end{array}$ \\
\hline GDP (log) & $\begin{array}{c}0.014 \\
(0.052)\end{array}$ & $\begin{array}{c}0.014 \\
(0.052)\end{array}$ & $\begin{array}{c}0.014 \\
(0.052)\end{array}$ & $\begin{array}{l}-0.001 \\
(0.047)\end{array}$ & $\begin{array}{l}-0.002 \\
(0.047)\end{array}$ \\
\hline NEA & $\begin{array}{l}-0.008 \\
(0.011)\end{array}$ & $\begin{array}{l}-0.008 \\
(0.011)\end{array}$ & $\begin{array}{l}-0.008 \\
(0.011)\end{array}$ & $\begin{array}{l}-0.008 \\
(0.010)\end{array}$ & $\begin{array}{l}-0.008 \\
(0.010)\end{array}$ \\
\hline $\begin{array}{l}\text { Entrepreneurship as a good } \\
\text { career choice (GEM) }\end{array}$ & $\begin{array}{c}0.001 \\
(0.003)\end{array}$ & $\begin{array}{c}0.001 \\
(0.003)\end{array}$ & $\begin{array}{c}0.001 \\
(0.003)\end{array}$ & $\begin{array}{c}0.000 \\
(0.002)\end{array}$ & $\begin{array}{c}0.000 \\
(0.002)\end{array}$ \\
\hline Access to finance & $\begin{array}{c}0.017 * * * \\
(0.003)\end{array}$ & $\begin{array}{l}0.015 * * * \\
(0.003)\end{array}$ & $\begin{array}{l}0.017 * * * \\
(0.003)\end{array}$ & $\begin{array}{l}0.015 * * * \\
(0.003)\end{array}$ & $\begin{array}{l}0.015 * * * \\
(0.003)\end{array}$ \\
\hline Laws & $\begin{array}{c}0.002 \\
(0.003) \\
\end{array}$ & $\begin{array}{c}0.003 \\
(0.003)\end{array}$ & $\begin{array}{c}0.002 \\
(0.003)\end{array}$ & $\begin{array}{c}0.004 \\
(0.003)\end{array}$ & $\begin{array}{c}0.004 \\
(0.003)\end{array}$ \\
\hline Economic environment & $\begin{array}{c}0.041 * * * \\
(0.003)\end{array}$ & $\begin{array}{c}0.042 * * * \\
(0.003)\end{array}$ & $\begin{array}{c}0.041 * * * \\
(0.003)\end{array}$ & $\begin{array}{c}0.042 * * * \\
(0.003)\end{array}$ & $\begin{array}{l}0.042 \% * \% \\
(0.003)\end{array}$ \\
\hline \multicolumn{6}{|c|}{ Moderating variable } \\
\hline Gender & $\begin{array}{c}-0.232 * * * \\
(0.012)\end{array}$ & $\begin{array}{c}-0.232 * * * \\
(0.012)\end{array}$ & $\begin{array}{c}-0.232 * * * \\
(0.012)\end{array}$ & $\begin{array}{c}-0.234 * * * \\
(0.012)\end{array}$ & $\begin{array}{c}-0.233 * * * \\
(0.012)\end{array}$ \\
\hline
\end{tabular}


Table 3 (end)

\begin{tabular}{|c|c|c|c|c|c|}
\hline Variable & Model 1 & Model 2 & Model 3 & Model 4 & Model 5 \\
\hline \multicolumn{6}{|c|}{ Independent variables } \\
\hline Family social support & & $\begin{array}{l}0.012 * * * \\
(0.003)\end{array}$ & & $\begin{array}{l}-0.005 \\
(0.004)\end{array}$ & $\begin{array}{l}0.008 * \\
(0.003)\end{array}$ \\
\hline University support & - & - & $\begin{array}{l}0.055 * * * \% \\
(0.004)\end{array}$ & $\begin{array}{l}0.055 * * * \\
(0.004)\end{array}$ & $\begin{array}{l}0.047 * * * \\
(0.005)\end{array}$ \\
\hline \multicolumn{6}{|c|}{ Interaction effects } \\
\hline $\begin{array}{l}\text { Family social support } \times \\
\text { Gender }\end{array}$ & - & - & - & $\begin{array}{l}0.031 * * * \\
(0.006)\end{array}$ & - \\
\hline University support $\times$ Gender & - & - & - & - & $\begin{array}{l}0.020 * \\
(0.008)\end{array}$ \\
\hline Constant & $\begin{array}{l}-0.410 \\
(0.625) \\
\end{array}$ & $\begin{array}{l}-0.436 \\
(0.625) \\
\end{array}$ & $\begin{array}{l}-0.248 \\
(0.563) \\
\end{array}$ & $\begin{array}{l}-0.224 \\
(0.565) \\
\end{array}$ & $\begin{array}{l}-0.257 \\
(0.564) \\
\end{array}$ \\
\hline Log-likelihood & -29104.293 & -29097.553 & -29024.74 & -29008.8 & -29018.91 \\
\hline$d f$ & 23 & 24 & 24 & 26 & 26 \\
\hline \multicolumn{6}{|c|}{ Random-effects parameters } \\
\hline Intercept (country) & $\begin{array}{l}0.013 * * * \\
(0.006)\end{array}$ & $\begin{array}{l}0.014 * \% * \\
(0.006)\end{array}$ & $\begin{array}{l}0.01 * \% * \\
(0.005)\end{array}$ & $\begin{array}{l}0.01 * \% * \\
(0.005)\end{array}$ & $\begin{array}{l}0.01 * * * \\
(0.005)\end{array}$ \\
\hline Intercept (university) & $\begin{array}{l}0.01 * * * \\
(0.003)\end{array}$ & $\begin{array}{l}0.01 * * * \\
(0.003)\end{array}$ & $\begin{array}{l}0.009 * * * \\
(0.002)\end{array}$ & $\begin{array}{l}0.009 * * * \\
(0.002)\end{array}$ & $\begin{array}{l}0.01 * * * \\
(0.002)\end{array}$ \\
\hline \multicolumn{6}{|c|}{ Model fit statistics } \\
\hline $\mathrm{AIC}$ & 58254.59 & 58243.11 & 58097.48 & 58069.61 & 58089.82 \\
\hline BIC & 58432.28 & 58428.53 & 58282.9 & 58270.48 & 58290.69 \\
\hline
\end{tabular}

N o t e: $N=16,744$; Poisson regression coefficients are reported (standard errors in parentheses); $P o b>C h i^{2}=0.000$ for all models; all models are statistically significant; $* * *, * *, *$ indicate significance at the $0.1 \%, 1 \%$ and $5 \%$ level, respectively; $\dagger$ — "Business and Economies" as a ref.cat., $\dagger$ — "Single" as a ref.cat.

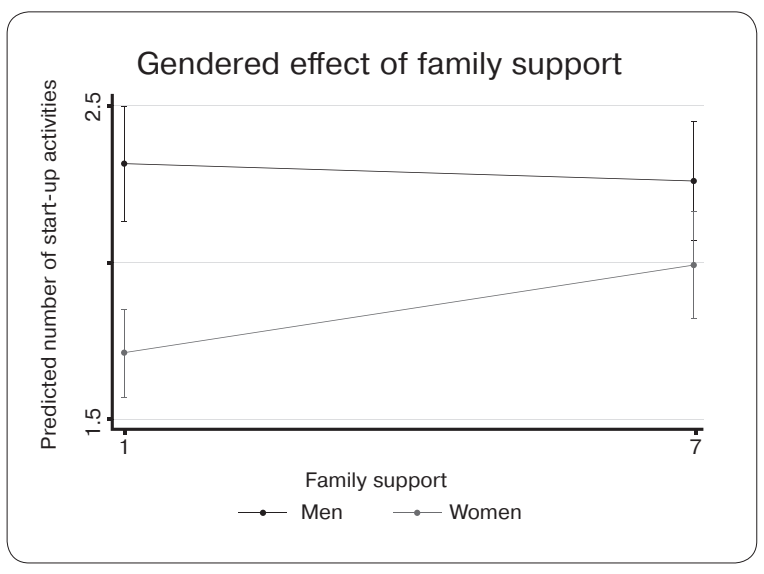

Fig. 1. Effect of family support on young men and women nascent entrepreneurs

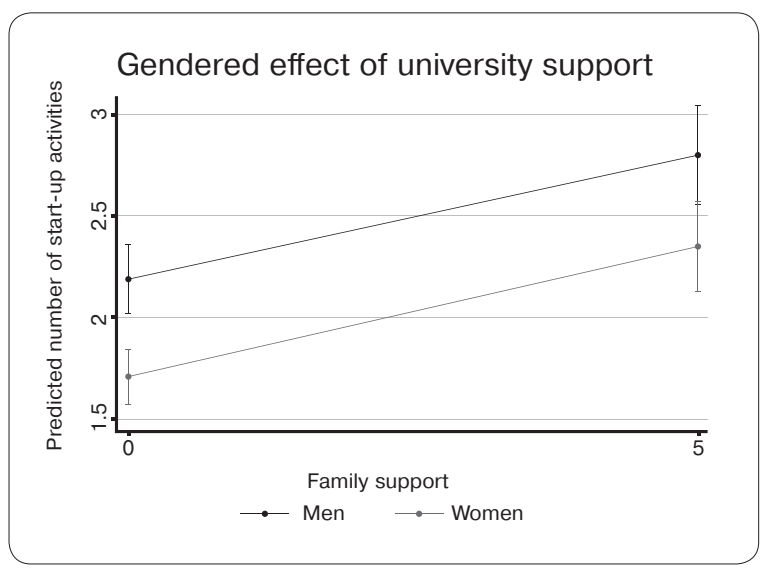

Fig. 2. Effect of university support on young men and women nascent entrepreneurs 
Table 4

Robustness tests: Poisson regression results for the progress in venturing process

\begin{tabular}{|c|c|c|c|c|c|}
\hline Variable & Model 1 & Model 2 & Model 3 & Model 4 & Model 5 \\
\hline \multicolumn{6}{|c|}{ Control variables } \\
\hline Age & $\begin{array}{l}0.018 * * * \\
(0.002)\end{array}$ & $\begin{array}{c}0.019 * * * \\
(0.002)\end{array}$ & $\begin{array}{l}0.019 * * * \\
(0.002)\end{array}$ & $\begin{array}{l}0.019 * * * \\
(0.002)\end{array}$ & $\begin{array}{l}0.019 * * * \\
(0.002)\end{array}$ \\
\hline Study level (bachelor) & $\begin{array}{l}-0.029 \\
(0.019) \\
\end{array}$ & $\begin{array}{l}-0.030 \\
(0.019) \\
\end{array}$ & $\begin{array}{l}-0.023 \\
(0.019) \\
\end{array}$ & $\begin{array}{l}-0.026 \\
(0.019) \\
\end{array}$ & $\begin{array}{l}-0.024 \\
(0.019) \\
\end{array}$ \\
\hline $\begin{array}{l}\text { Field of study (natural } \\
\text { science) } \dagger\end{array}$ & $\begin{array}{c}0.004 \\
(0.016)\end{array}$ & $\begin{array}{c}0.005 \\
(0.016)\end{array}$ & $\begin{array}{c}0.006 \\
(0.016)\end{array}$ & $\begin{array}{c}0.004 \\
(0.016)\end{array}$ & $\begin{array}{c}0.006 \\
(0.016)\end{array}$ \\
\hline $\begin{array}{l}\text { Field of study (social } \\
\text { science) }\end{array}$ & $\begin{array}{l}-0.034 \\
(0.025) \\
\end{array}$ & $\begin{array}{l}-0.032 \\
(0.025) \\
\end{array}$ & $\begin{array}{l}-0.030 \\
(0.025) \\
\end{array}$ & $\begin{array}{l}-0.027 \\
(0.025) \\
\end{array}$ & $\begin{array}{l}-0.027 \\
(0.025) \\
\end{array}$ \\
\hline Field of study (other) & $\begin{array}{l}-0.011 \\
(0.016)\end{array}$ & $\begin{array}{l}-0.011 \\
(0.016)\end{array}$ & $\begin{array}{l}-0.007 \\
(0.016)\end{array}$ & $\begin{array}{l}-0.008 \\
(0.016)\end{array}$ & $\begin{array}{l}-0.008 \\
(0.016)\end{array}$ \\
\hline Family background & $\begin{array}{l}0.087 * * * \\
(0.012)\end{array}$ & $\begin{array}{c}0.079 * * * \\
(0.012)\end{array}$ & $\begin{array}{l}0.082 * * * \\
(0.012)\end{array}$ & $\begin{array}{l}0.077 * * * \\
(0.012)\end{array}$ & $\begin{array}{l}0.077 * * * \\
(0.012)\end{array}$ \\
\hline Entrepreneurship courses & $\begin{array}{l}0.161 * * * \\
(0.014)\end{array}$ & $\begin{array}{c}0.159 * * * \\
(0.014)\end{array}$ & $\begin{array}{l}0.116 * * * \\
(0.015)\end{array}$ & $\begin{array}{l}0.114 * * * \\
(0.015)\end{array}$ & $\begin{array}{l}0.116 * * * \\
(0.015)\end{array}$ \\
\hline Previous experience & $\begin{array}{l}0.297 * * * \\
(0.012)\end{array}$ & $\begin{array}{l}0.296 * * * \\
(0.012)\end{array}$ & $\begin{array}{l}0.291 * * * \\
(0.012)\end{array}$ & $\begin{array}{l}0.291 * * * \\
(0.012)\end{array}$ & $\begin{array}{l}0.291 * \% * \\
(0.012)\end{array}$ \\
\hline Commitment & $\begin{array}{l}0.001 \% * \% \\
(0.000)\end{array}$ & $\begin{array}{c}0.001 * * * \\
(0.000)\end{array}$ & $\begin{array}{l}0.001 * * \% \\
(0.000)\end{array}$ & $\begin{array}{l}0.001 * * * \\
(0.000)\end{array}$ & $\begin{array}{l}0.001 \% * \% \\
(0.000)\end{array}$ \\
\hline Partners & $\begin{array}{l}0.101 * * * \\
(0.006)\end{array}$ & $\begin{array}{l}0.101 * * * \\
(0.006)\end{array}$ & $\begin{array}{l}0.100 * * * \\
(0.006)\end{array}$ & $\begin{array}{l}0.099 * * * \\
(0.006)\end{array}$ & $\begin{array}{l}0.100 * * * \\
(0.006)\end{array}$ \\
\hline Cohesiveness & $\begin{array}{l}-0.010 \\
(0.008)\end{array}$ & $\begin{array}{l}-0.018 * \\
(0.008)\end{array}$ & $\begin{array}{l}-0.017 * \\
(0.008)\end{array}$ & $\begin{array}{l}-0.022 * * \\
(0.008)\end{array}$ & $\begin{array}{l}-0.022 * \% \\
(0.008)\end{array}$ \\
\hline Status (married) $\dagger$ & $\begin{array}{c}0.013 \\
(0.020)\end{array}$ & $\begin{array}{c}0.014 \\
(0.020)\end{array}$ & $\begin{array}{c}0.014 \\
(0.020)\end{array}$ & $\begin{array}{c}0.016 \\
(0.020)\end{array}$ & $\begin{array}{c}0.015 \\
(0.020)\end{array}$ \\
\hline Status (divorced) & $\begin{array}{c}0.042 \\
(0.069) \\
\end{array}$ & $\begin{array}{c}0.047 \\
(0.069) \\
\end{array}$ & $\begin{array}{c}0.041 \\
(0.069)\end{array}$ & $\begin{array}{c}0.048 \\
(0.069) \\
\end{array}$ & $\begin{array}{c}0.045 \\
(0.069) \\
\end{array}$ \\
\hline GDP $(\log )$ & - & - & - & - & - \\
\hline NEA & - & - & - & - & - \\
\hline $\begin{array}{l}\text { Entrepreneurship as a good } \\
\text { career choice (GEM) }\end{array}$ & - & - & - & - & - \\
\hline Access to finance & $\begin{array}{l}0.017 * * * \\
(0.003)\end{array}$ & $\begin{array}{l}0.016 * * * \\
(0.003)\end{array}$ & $\begin{array}{l}0.016 * * * \\
(0.003)\end{array}$ & $\begin{array}{l}0.015 * \% * \\
(0.003)\end{array}$ & $\begin{array}{l}0.016 * \% * \\
(0.003)\end{array}$ \\
\hline Laws & $\begin{array}{c}0.002 \\
(0.003)\end{array}$ & $\begin{array}{c}0.003 \\
(0.003)\end{array}$ & $\begin{array}{c}0.003 \\
(0.003)\end{array}$ & $\begin{array}{c}0.004 \\
(0.003)\end{array}$ & $\begin{array}{c}0.004 \\
(0.003)\end{array}$ \\
\hline Economic environment & $\begin{array}{l}0.041 * * * \\
(0.003)\end{array}$ & $\begin{array}{l}0.041 * * * \\
(0.003)\end{array}$ & $\begin{array}{l}0.042 * * * \\
(0.003)\end{array}$ & $\begin{array}{c}0.042 * * * \\
(0.003)\end{array}$ & $\begin{array}{l}0.042 * * * \\
(0.003)\end{array}$ \\
\hline \multicolumn{6}{|c|}{ Moderating variable } \\
\hline Gender & $\begin{array}{l}-0.235 * * * \\
(0.012)\end{array}$ & $\begin{aligned} &-0.235 * * * \\
&(0.012)\end{aligned}$ & $\begin{array}{l}-0.233 * * * \\
(0.012)\end{array}$ & $\begin{aligned}-0.237 * * * \\
\\
(0.012)\end{aligned}$ & $\begin{array}{l}-0.236 * * \% \\
(0.012)\end{array}$ \\
\hline
\end{tabular}


Table 4 (end)

\begin{tabular}{|c|c|c|c|c|c|}
\hline Variable & Model 1 & Model 2 & Model 3 & Model 4 & Model 5 \\
\hline \multicolumn{6}{|c|}{ Independent variables } \\
\hline Family social support & - & $\begin{array}{l}0.012 * * * \\
(0.003)\end{array}$ & - & $\begin{array}{l}-0.004 \\
(0.004)\end{array}$ & $\begin{array}{l}0.008 * \\
(0.003)\end{array}$ \\
\hline University support & - & - & $\begin{array}{l}0.053 * * \% \\
(0.004)\end{array}$ & $\begin{array}{l}0.052 * * * \\
(0.004)\end{array}$ & $\begin{array}{l}0.045 * * \% \\
(0.005)\end{array}$ \\
\hline \multicolumn{6}{|c|}{ Interaction effects } \\
\hline $\begin{array}{l}\text { Family social support } \times \\
\text { Gender }\end{array}$ & - & - & - & $\begin{array}{l}0.031 * * * \\
(0.006)\end{array}$ & - \\
\hline University support $\times$ Gender & - & - & - & - & $\begin{array}{l}0.020 * \\
(0.008)\end{array}$ \\
\hline Constant & $\begin{array}{l}-0.648 * * * \\
(0.120)\end{array}$ & $\begin{array}{l}-0.679 * * * \\
(0.121)\end{array}$ & $\begin{array}{l}-0.665 * * * \\
(0.120)\end{array}$ & $\begin{array}{l}-0.635 * * * \\
(0.121)\end{array}$ & $\begin{array}{l}-0.678 * * * \\
(0.121)\end{array}$ \\
\hline Pseudo $R^{2}$ & 0.0577 & 0.0579 & 0.0600 & 0.0605 & 0.0602 \\
\hline
\end{tabular}

Not e: $N=16.744$; Poisson regression coefficients are reported (standard errors in parentheses); $P o b>C h i^{2}=0.000$ for all models; all models are statistically significant; ***, **, * indicate significance at the $0.1 \%, 1 \%$ and $5 \%$ level, respectively; $\dagger$ - "Business and Economies" as a ref.cat., $\dagger$ — "Single" as a ref.cat.

of family networks is stronger for female students and almost unnoticeable for male students.

The interaction between university support and gender is significant but not in the expected direction (Model 5, $\beta=0.020, p<0.05$ ). Thus, Hypothesis $3 \mathrm{~b}$ is rejected because the effect of university support in the venturing process was found to be stronger for female students than for male students. Examining the interaction effect, we establish that both men and women benefit from university support in their entrepreneurial initiatives, and women appear to benefit slightly more (i.e. the slope of the line is slightly steeper for women, compared to men). The gendered effect of university support on the venturing progress (number of start-up activities) is visualized in Figure 2.

\section{ROBUSTNESS CHECKS}

In addition to our primary analysis, we ran several alternative specifications to the em- pirical model to ensure the robustness of our results.

First, in order to get a more fine-grained picture of the effects of our independent variables of interest, we ran a simple Poisson regression as an alternative model, adding dummies for universities. The results (reported in Table 4) are consistent with the multi-level regression results.

Second, to ascertain the effect of university support, we ran a robustness check by examining the effect of an alternative measure, university learning (adapted from [Souitaris, Zerbinati, Al-Laham, 2007; Sieger, Fueglistaller, Zellweger, 2011]), as an independent variable (Table 5). All coefficients remained in the same direction and the significance levels were retained.

Third, we ran our model with an alternative dependent variable - a weighted index instead of a simple tally of activities. Following [Sieger, Fueglistaller, Zellweger, 2011], the index is calculated based on the formula: Index $=1 *$ (nothing done) $+3 *$ $*$ (thought of first business ideas) $+5 *$ (formulated business plan + identified market 
HLM estimates of the progress

\begin{tabular}{|c|c|c|c|c|c|}
\hline \multirow{2}{*}{ Variable } & \multicolumn{5}{|c|}{ Alternative variable for the university effect } \\
\hline & 1 & 2 & 3 & 4 & 5 \\
\hline \multicolumn{6}{|c|}{ Control variables } \\
\hline Age & $\begin{array}{c}0.018 * * * \\
(0.002)\end{array}$ & $\begin{array}{c}0.019 * * * \\
(0.002)\end{array}$ & $\begin{array}{l}0.019 * * * \\
(0.002)\end{array}$ & $\begin{array}{l}0.019 * * * \\
(0.002)\end{array}$ & $\begin{array}{l}0.020 * * * \\
(0.002)\end{array}$ \\
\hline Study level (bachelor) & $\begin{array}{l}-0.022 \\
(0.018)\end{array}$ & $\begin{array}{l}-0.023 \\
(0.018)\end{array}$ & $\begin{array}{l}-0.021 \\
(0.018)\end{array}$ & $\begin{array}{l}-0.023 \\
(0.018)\end{array}$ & $\begin{array}{l}-0.022 \\
(0.018)\end{array}$ \\
\hline $\begin{array}{l}\text { Field of study (natural } \\
\text { science) } \dagger\end{array}$ & $\begin{array}{c}0.007 \\
(0.015)\end{array}$ & $\begin{array}{c}0.008 \\
(0.015)\end{array}$ & $\begin{array}{c}0.02 \\
(0.015)\end{array}$ & $\begin{array}{c}0.018 \\
(0.015)\end{array}$ & $\begin{array}{c}0.020 \\
(0.015)\end{array}$ \\
\hline $\begin{array}{l}\text { Field of study (social } \\
\text { science) }\end{array}$ & $\begin{array}{l}-0.031 \\
(0.025)\end{array}$ & $\begin{array}{l}-0.030 \\
(0.025)\end{array}$ & $\begin{array}{l}-0.019 \\
(0.025)\end{array}$ & $\begin{array}{l}-0.017 \\
(0.025)\end{array}$ & $\begin{array}{l}-0.014 \\
(0.025)\end{array}$ \\
\hline Field of study (other) & $\begin{array}{l}-0.004 \\
(0.015)\end{array}$ & $\begin{array}{l}-0.004 \\
(0.015)\end{array}$ & $\begin{array}{c}0.004 \\
(0.015)\end{array}$ & $\begin{array}{c}0.004 \\
(0.015)\end{array}$ & $\begin{array}{c}0.005 \\
(0.015)\end{array}$ \\
\hline Family background & $\begin{array}{c}0.086 * * * \\
(0.012)\end{array}$ & $\begin{array}{c}0.079 * * * \\
(0.012)\end{array}$ & $\begin{array}{c}0.086 * * * \\
(0.012)\end{array}$ & $\begin{array}{c}0.080 * * * \\
(0.012)\end{array}$ & $\begin{array}{c}0.080 * * * \\
(0.012)\end{array}$ \\
\hline Entrepreneurship courses & $\begin{array}{c}0.167 * * * \\
(0.014)\end{array}$ & $\begin{array}{c}0.166 * * * \\
(0.014)\end{array}$ & $\begin{array}{c}0.147 * * * \\
(0.014)\end{array}$ & $\begin{array}{c}0.146 * * * \\
(0.014)\end{array}$ & $\begin{array}{c}0.146 * * * \\
(0.014)\end{array}$ \\
\hline Previous experience & $\begin{array}{c}0.297 * * * \\
(0.012)\end{array}$ & $\begin{array}{c}0.296 * * * \\
(0.012)\end{array}$ & $\begin{array}{c}0.294 * * * \\
(0.012)\end{array}$ & $\begin{array}{c}0.293 * * * \\
(0.012)\end{array}$ & $\begin{array}{c}0.294 * * * \\
(0.012)\end{array}$ \\
\hline Commitment & $\begin{array}{c}0.002 * * * \\
(0.000)\end{array}$ & $\begin{array}{c}0.002 * * * \\
(0.000)\end{array}$ & $\begin{array}{c}0.002 * * * \\
(0.000)\end{array}$ & $\begin{array}{c}0.001 * * * \\
(0.000)\end{array}$ & $\begin{array}{c}0.001 * * * \\
(0.000)\end{array}$ \\
\hline Partners & $\begin{array}{c}0.102 * * * \\
(0.006)\end{array}$ & $\begin{array}{c}0.102 * * * \\
(0.006)\end{array}$ & $\begin{array}{c}0.101 * * * \\
(0.006)\end{array}$ & $\begin{array}{c}0.101 * * * \\
(0.006)\end{array}$ & $\begin{array}{c}0.101 * * * \\
(0.006)\end{array}$ \\
\hline Cohesiveness & $\begin{array}{c}-0.012 \% \\
(0.008)\end{array}$ & $\begin{array}{c}-0.020 \% \\
(0.008)\end{array}$ & $\begin{array}{c}-0.021 * * * \\
(0.008)\end{array}$ & $\begin{array}{c}-0.027 * * * \\
(0.008)\end{array}$ & $\begin{array}{c}-0.027 * * * \\
(0.008)\end{array}$ \\
\hline Status (married) $\dagger \dagger$ & $\begin{array}{c}0.013 \\
(0.020)\end{array}$ & $\begin{array}{c}0.013 \\
(0.020)\end{array}$ & $\begin{array}{c}0.009 \\
(0.020)\end{array}$ & $\begin{array}{c}0.010 \\
(0.020)\end{array}$ & $\begin{array}{c}0.011 \\
(0.020)\end{array}$ \\
\hline Status (divorced) & $\begin{array}{c}0.053 \\
(0.068) \\
\end{array}$ & $\begin{array}{c}0.058 \\
(0.068) \\
\end{array}$ & $\begin{array}{c}0.05 \\
(0.068) \\
\end{array}$ & $\begin{array}{c}0.057 \\
(0.068) \\
\end{array}$ & $\begin{array}{c}0.056 \\
(0.068) \\
\end{array}$ \\
\hline GDP (log) & $\begin{array}{c}0.014 \\
(0.052)\end{array}$ & $\begin{array}{c}0.014 \\
(0.052)\end{array}$ & $\begin{array}{c}0.014 \\
(0.052)\end{array}$ & $\begin{array}{c}0.014 \\
(0.052)\end{array}$ & $\begin{array}{c}0.015 \\
(0.052)\end{array}$ \\
\hline NEA & $\begin{array}{l}-0.008 \\
(0.011)\end{array}$ & $\begin{array}{l}-0.008 \\
(0.011)\end{array}$ & $\begin{array}{l}-0.008 \\
(0.011)\end{array}$ & $\begin{array}{l}-0.009 \\
(0.011)\end{array}$ & $\begin{array}{l}-0.009 \\
(0.011)\end{array}$ \\
\hline $\begin{array}{l}\text { Entrepreneurship as a good } \\
\text { career choice (GEM) }\end{array}$ & $\begin{array}{c}0.001 \\
(0.003) \\
\end{array}$ & $\begin{array}{c}0.001 \\
(0.003) \\
\end{array}$ & $\begin{array}{c}0.001 \\
(0.003) \\
\end{array}$ & $\begin{array}{c}0.001 \\
(0.003) \\
\end{array}$ & $\begin{array}{c}0.001 \\
(0.003) \\
\end{array}$ \\
\hline Access to finance & $\begin{array}{c}0.017 * * * \\
(0.003)\end{array}$ & $\begin{array}{c}0.015 * * * \\
(0.003)\end{array}$ & $\begin{array}{c}0.016 * * * \\
(0.003)\end{array}$ & $\begin{array}{l}0.015 * * * \\
(0.003)\end{array}$ & $\begin{array}{c}0.015 * * * \\
(0.003)\end{array}$ \\
\hline $\begin{array}{l}\text { Laws } \\
\end{array}$ & $\begin{array}{c}0.002 \\
(0.003)\end{array}$ & $\begin{array}{c}0.003 \\
(0.003)\end{array}$ & $\begin{array}{c}0.002 \\
(0.003)\end{array}$ & $\begin{array}{c}0.003 \\
(0.003)\end{array}$ & $\begin{array}{c}0.003 \\
(0.003)\end{array}$ \\
\hline Economic environment & $\begin{array}{c}0.041 * * * \\
(0.003)\end{array}$ & $\begin{array}{c}0.042 * * * \\
(0.003)\end{array}$ & $\begin{array}{l}0.041 * * * \\
(0.003)\end{array}$ & $\begin{array}{l}0.041 * * * \\
(0.003)\end{array}$ & $\begin{array}{l}0.042 * * * \\
(0.003)\end{array}$ \\
\hline
\end{tabular}


Table 5

in venturing process

\begin{tabular}{|c|c|c|c|c|}
\hline \multicolumn{5}{|c|}{ Alternative dependent variable } \\
\hline 1 & 2 & 3 & 4 & 5 \\
\hline $\begin{array}{c}0.226 * * * \\
(0.023)\end{array}$ & $\begin{array}{c}0.227 * * * \\
(0.024)\end{array}$ & $\begin{array}{c}0.225 * * * \\
(0.023)\end{array}$ & $\begin{array}{c}0.230 * * * \\
(0.024)\end{array}$ & $\begin{array}{c}0.232 * * * \\
(0.024)\end{array}$ \\
\hline $\begin{array}{l}-0.053 \\
(0.217)\end{array}$ & $\begin{array}{l}-0.065 \\
(0.217)\end{array}$ & $\begin{array}{c}-0.01 \\
(0.216)\end{array}$ & $\begin{array}{l}-0.028 \\
(0.216)\end{array}$ & $\begin{array}{l}-0.016 \\
(0.216)\end{array}$ \\
\hline $\begin{array}{c}0.260 \\
(0.183)\end{array}$ & $\begin{array}{c}0.270 \\
(0.183)\end{array}$ & $\begin{array}{c}0.304 \\
(0.181)\end{array}$ & $\begin{array}{c}0.286 \\
(0.181)\end{array}$ & $\begin{array}{c}0.312 \\
(0.181)\end{array}$ \\
\hline $\begin{array}{l}-0.079 \\
(0.285)\end{array}$ & $\begin{array}{l}-0.065 \\
(0.285)\end{array}$ & $\begin{array}{l}-0.026 \\
(0.283)\end{array}$ & $\begin{array}{l}-0.007 \\
(0.283)\end{array}$ & $\begin{array}{l}-0.027 \\
(0.283)\end{array}$ \\
\hline $\begin{array}{c}0.070 \\
(0.185)\end{array}$ & $\begin{array}{c}0.070 \\
(0.185)\end{array}$ & $\begin{array}{c}0.114 \\
(0.184)\end{array}$ & $\begin{array}{c}0.117 \\
(0.184)\end{array}$ & $\begin{array}{c}0.110 \\
(0.184)\end{array}$ \\
\hline $\begin{array}{l}1.02 * \% * \\
(0.142)\end{array}$ & $\begin{array}{c}0.940 * * * \\
(0.144)\end{array}$ & $\begin{array}{c}0.974 * * * \\
(0.141)\end{array}$ & $\begin{array}{c}0.920 * * * \\
(0.143)\end{array}$ & $\begin{array}{c}0.924 * * * \\
(0.143)\end{array}$ \\
\hline $\begin{array}{c}1.665 * * * \\
(0.162)\end{array}$ & $\begin{array}{c}1.646 * * * \\
(0.162)\end{array}$ & $\begin{array}{c}1.089 * * * \\
(0.168)\end{array}$ & $\begin{array}{c}1.078 * * * \\
(0.168)\end{array}$ & $\begin{array}{c}1.087 * * * \\
(0.168)\end{array}$ \\
\hline $\begin{array}{c}3.334 \% * \% \\
(0.145)\end{array}$ & $\begin{array}{c}3.325 * * * \\
(0.145)\end{array}$ & $\begin{array}{c}3.262 * \% * \\
(0.145)\end{array}$ & $\begin{array}{c}3.254 * * * \\
(0.145)\end{array}$ & $\begin{array}{c}3.257 * * * \\
(0.145)\end{array}$ \\
\hline $\begin{array}{c}0.014 * * * \\
(0.002)\end{array}$ & $\begin{array}{c}0.013 * * * \\
(0.002)\end{array}$ & $\begin{array}{c}0.013 * * * \\
(0.002)\end{array}$ & $\begin{array}{c}0.013 * * * \\
(0.002)\end{array}$ & $\begin{array}{c}0.013 * * * \\
(0.002)\end{array}$ \\
\hline $\begin{array}{c}1.053 * * * \\
(0.072)\end{array}$ & $\begin{array}{c}1.052 * * * \\
(0.072)\end{array}$ & $\begin{array}{c}1.031 * * * \\
(0.072)\end{array}$ & $\begin{array}{c}1.028 * * * \\
(0.072)\end{array}$ & $\begin{array}{c}1.031 * * * \\
(0.072)\end{array}$ \\
\hline $\begin{array}{c}-0.143 * \\
(0.093)\end{array}$ & $\begin{array}{c}-0.227 * \\
(0.096)\end{array}$ & $\begin{array}{c}-0.220 * \% \\
(0.093)\end{array}$ & $\begin{array}{c}-0.271 * * \\
(0.096)\end{array}$ & $\begin{array}{c}-0.272 \% * \\
(0.096)\end{array}$ \\
\hline $\begin{array}{c}0.257 \\
(0.261)\end{array}$ & $\begin{array}{c}0.265 \\
(0.261)\end{array}$ & $\begin{array}{c}0.275 \\
(0.260)\end{array}$ & $\begin{array}{c}0.289 \\
(0.259)\end{array}$ & $\begin{array}{c}0.279 \\
(0.259)\end{array}$ \\
\hline $\begin{array}{c}0.90 \\
(0.903)\end{array}$ & $\begin{array}{c}0.946 \\
(0.903)\end{array}$ & $\begin{array}{c}0.90 \\
(0.899)\end{array}$ & $\begin{array}{c}0.960 \\
(0.899)\end{array}$ & $\begin{array}{c}0.922 \\
(0.899)\end{array}$ \\
\hline $\begin{array}{c}0.276 \\
(0.594)\end{array}$ & $\begin{array}{c}0.275 \\
(0.594)\end{array}$ & $\begin{array}{c}0.070 \\
(0.527)\end{array}$ & $\begin{array}{c}0.074 \\
(0.528)\end{array}$ & $\begin{array}{c}0.073 \\
(0.529)\end{array}$ \\
\hline $\begin{array}{l}-0.014 \\
(0.128)\end{array}$ & $\begin{array}{l}-0.022 \\
(0.128)\end{array}$ & $\begin{array}{l}-0.017 \\
(0.114)\end{array}$ & $\begin{array}{l}-0.020 \\
(0.114)\end{array}$ & $\begin{array}{l}-0.022 \\
(0.114)\end{array}$ \\
\hline $\begin{array}{l}-0.001 \\
(0.030)\end{array}$ & $\begin{array}{l}-0.002 \\
(0.030)\end{array}$ & $\begin{array}{l}-0.007 \\
(0.027)\end{array}$ & $\begin{array}{l}-0.006 \\
(0.027)\end{array}$ & $\begin{array}{l}-0.007 \\
(0.027)\end{array}$ \\
\hline $\begin{array}{c}0.247 * * * \\
(0.041)\end{array}$ & $\begin{array}{c}0.234 * * * \\
(0.041)\end{array}$ & $\begin{array}{c}0.237 * * * \\
(0.041)\end{array}$ & $\begin{array}{c}0.226 * * * \\
(0.041)\end{array}$ & $\begin{array}{c}0.228 * * * \\
(0.041)\end{array}$ \\
\hline $\begin{array}{l}-0.005 \\
(0.041)\end{array}$ & $\begin{array}{c}0.009 \\
(0.041)\end{array}$ & $\begin{array}{c}0.013 \\
(0.041)\end{array}$ & $\begin{array}{c}0.020 \\
(0.041)\end{array}$ & $\begin{array}{c}0.021 \\
(0.041)\end{array}$ \\
\hline $\begin{array}{c}0.435 * * * \\
(0.043)\end{array}$ & $\begin{array}{c}0.438 * * * \\
(0.043)\end{array}$ & $\begin{array}{c}0.441 * * * \\
(0.043)\end{array}$ & $\begin{array}{c}0.441 * * * \\
(0.043)\end{array}$ & $\begin{array}{c}0.444 * * * \\
(0.043)\end{array}$ \\
\hline
\end{tabular}




\begin{tabular}{|c|c|c|c|c|c|}
\hline \multirow{2}{*}{ Variable } & \multicolumn{5}{|c|}{ Alternative variable for the university effect } \\
\hline & 1 & 2 & 3 & 4 & 5 \\
\hline \multicolumn{6}{|c|}{ Moderating variable } \\
\hline Gender & $\begin{array}{c}-0.232 * * * \\
(0.012)\end{array}$ & $\begin{array}{c}-0.232 * * * \\
(0.012)\end{array}$ & $\begin{array}{c}-0.231 * * * \\
(0.012)\end{array}$ & $\begin{array}{c}-0.235 * * * \\
(0.012)\end{array}$ & $\begin{array}{c}-0.237 * * * \\
(0.012)\end{array}$ \\
\hline \multicolumn{6}{|c|}{ Independent variable } \\
\hline Family social support & - & $\begin{array}{l}0.012 * * * \\
(0.003)\end{array}$ & - & $\begin{array}{l}-0.002 \\
(0.004)\end{array}$ & $\begin{array}{l}0.010 * \% \\
(0.003)\end{array}$ \\
\hline University support & - & - & $\begin{array}{l}0.034 * * * \\
(0.004)\end{array}$ & $\begin{array}{l}0.032 * * * \\
(0.004)\end{array}$ & $\begin{array}{c}0.019 * * * \\
(0.006)\end{array}$ \\
\hline \multicolumn{6}{|c|}{ Interaction effect } \\
\hline $\begin{array}{l}\text { Family social support } \times \\
\text { Gender }\end{array}$ & & & & $\begin{array}{l}0.030 * * * \\
(0.006)\end{array}$ & \\
\hline University support $\times$ Gender & & & & & $\begin{array}{l}0.032 * * * \\
(0.008)\end{array}$ \\
\hline Constant & $\begin{array}{l}-0.410 \\
(0.625)\end{array}$ & $\begin{array}{l}-0.436 \\
(0.610)\end{array}$ & $\begin{array}{l}-0.535 \\
(0.611)\end{array}$ & $\begin{array}{l}-0.510 \\
(0.609)\end{array}$ & $\begin{array}{l}-0.507 \\
(0.625)\end{array}$ \\
\hline Log-likelhood & -29104.293 & -29097.55 & -29075.26 & -29058.95 & -29063.36 \\
\hline$d f$ & 23 & 24 & 23 & 26 & 26 \\
\hline \multicolumn{6}{|c|}{ Random-effects parameter } \\
\hline Intercept (country) & $\begin{array}{c}0.014 \\
(0.006)\end{array}$ & $\begin{array}{c}0.014 \\
(0.006)\end{array}$ & $\begin{array}{c}0.013 \\
(0.006)\end{array}$ & $\begin{array}{c}0.013 \\
(0.006)\end{array}$ & $\begin{array}{c}0.013 \\
(0.006)\end{array}$ \\
\hline Intercept (university) & $\begin{array}{c}0.01 \\
(0.003)\end{array}$ & $\begin{array}{c}0.01 \\
(0.003)\end{array}$ & $\begin{array}{c}0.01 \\
(0.002)\end{array}$ & $\begin{array}{c}0.01 \\
(0.002)\end{array}$ & $\begin{array}{c}0.01 \\
(0.002)\end{array}$ \\
\hline \multicolumn{6}{|c|}{ Model fit statistics } \\
\hline $\mathrm{AIC}$ & 58254.59 & 58243.11 & 58196.52 & 58169.91 & 58178.72 \\
\hline $\mathrm{BIC}$ & 58432.28 & 58428.53 & 58374.21 & 58370.78 & 58379.59 \\
\hline
\end{tabular}

N o t e: $N=16.744$; Poisson regression coefficients are reported (standard errors in parentheses); $P o b>C h i^{2}=0.000$ for all models; all models are statistically significant; $* * *, *, *$ indicate significance at the $0.1 \%, 1 \%$ and $5 \%$ level, respectively; $\dagger$ - "Business and Economies" as a ref.cat., $\dagger$ — "Single" as a ref.cat.

opportunity + looked for potential partners) $+7 *$ (purchased equipment + worked on product development + discussed with potential partners + asked financial institutions for funding) $+10 *$ (decided on date of founding). The results of this alternative specification are reported in Table 5, and they are substantially the same as the results from the multilevel mixed effects Poisson estimation.

From our tests, we can conclude that our results are robust to alternative operation- alization of the independent and dependent variables, and to alternative regression specifications.

\section{DISCUSSION}

In this paper, we rely on the rich literature around social networks to explore two different contexts in which the nascent student 
Table 5 (end)

\begin{tabular}{|c|c|c|c|c|}
\hline \multicolumn{5}{|c|}{ Alternative dependent variable } \\
\hline 1 & 2 & 3 & 4 & 5 \\
\hline $\begin{array}{c}-2.390 * * * \\
(0.144)\end{array}$ & $\begin{array}{c}-2.390 * \% * \\
(0.144)\end{array}$ & $\begin{array}{c}-2.364 * * * \\
(0.143)\end{array}$ & $\begin{array}{c}-2.379 * * * \\
(0.143)\end{array}$ & $\begin{array}{c}-2.362 * * * \\
(0.143)\end{array}$ \\
\hline- & $\begin{array}{l}0.133 * * * \\
(0.040)\end{array}$ & - & $\begin{array}{l}-0.040 \\
(0.053)\end{array}$ & $\begin{array}{l}0.082 * \\
(0.040)\end{array}$ \\
\hline- & - & $\begin{array}{l}0.722 * * * \\
(0.057)\end{array}$ & $\begin{array}{c}0.712 * * * \\
(0.057)\end{array}$ & $\begin{array}{c}0.770 * * \% \\
(0.073)\end{array}$ \\
\hline & & & $\begin{array}{c}0.259 * * * \\
(0.073)\end{array}$ & \\
\hline & & & & $\begin{array}{l}-0.138 \\
(0.106)\end{array}$ \\
\hline $\begin{array}{c}-3.352 \\
(7.2)\end{array}$ & $\begin{array}{c}-3.646 \\
(6.37) \\
\end{array}$ & $\begin{array}{l}-1.244 \\
(6.381) \\
\end{array}$ & $\begin{array}{l}-1.015 \\
(6.396) \\
\end{array}$ & $\begin{array}{c}-1.519 \\
(7.2) \\
\end{array}$ \\
\hline-60186.83 & -60181.34 & -60106.7 & -60098.23 & -60103.73 \\
\hline 24 & 25 & 25 & 27 & 27 \\
\hline $\begin{array}{c}1.865 \\
(0.852)\end{array}$ & $\begin{array}{c}1.862 \\
(0.852)\end{array}$ & $\begin{array}{c}1.412 \\
(0.674)\end{array}$ & $\begin{array}{l}1.415 \\
(0.679)\end{array}$ & $\begin{array}{c}1.425 \\
(0.679)\end{array}$ \\
\hline $\begin{array}{c}0.745 \\
(0.269)\end{array}$ & $\begin{array}{c}0.737 \\
(0.269)\end{array}$ & $\begin{array}{c}0.634 \\
(0.247)\end{array}$ & $\begin{array}{c}0.636 \\
(0.247)\end{array}$ & $\begin{array}{c}0.626 \\
(0.246)\end{array}$ \\
\hline & 120412.7 & 120263.4 & 120250.5 & 120261.5 \\
\hline 120607.1 & 120605.8 & 120456.5 & 120459.1 & 120470.1 \\
\hline
\end{tabular}

entrepreneur is embedded, the family and the university. Then, drawing on social network theory and ideas around homophily, we empirically test to see if the family and university context has a differential effect on the nascent entrepreneur based on his or her sex. In doing so, we begin to untangle the subtle influences that gender may have on the nascent entrepreneurs' progress through the venturing process, and thus in a small way begin to make sense of the inherent chaos in the gestation process.

\subsection{Gender and the effect of family social contacts}

Family ties are strong ties. They are ties formed from long-standing relationships based on frequent contacts [Coleman, 1988]. Theory suggests that they are the most reliable rela- 
tionships as they are based on principles of reciprocity and trust. Entrepreneurs make substantial investments in strong tie relationships, as they require frequent contact, are typically more reliable, and involve emotional closeness.

Our study highlights that "strong ties" within a family are not just a source of "bonding" social capital in the form of emotional support, but also a source of external "bridging social capital", in the form of passing valuable social contacts and/or entry into the family's existing social networks. Introductions made by family members are likely to be more profitable because of the family members' willingness to look out for the best interests of, in this case, their children [Karra, Tracey, Phillips, 2006]. In other words, parents help their children overcome the barriers to entry into self-employment by providing them access to valuable resources, one of which is their social networks.

Family social capital may have a strong influence on the venture creation process even when the family is not directly involved in the entrepreneurial initiative [Aldrich, Cliff, 2003; Alsos, Carter, Ljunggren, 2014; Renzulli, Aldrich, Moody, 2000; Steier, 2007]. Affiliation with a well-respected family is often interpreted as a signal of positive personal traits and ascribed status. In addition, families take responsibility for the obligations and actions of their members. This allows social actors to "borrow" the family's established social capital in the process of completing early-stage start-up activities. In sum, family social capital provides information and opens doors for young entrepreneurs, thus facilitating the completion of founding activities.

However, when we take a fine-grained look at the gender differences, we find that women student entrepreneurs benefit more from their family's social contacts than do men. Indeed, descriptive statistics indicate that women rate the importance of family support significantly higher than men do. Family support fosters the progress of women through the venturing process, while (somewhat un- expectedly), it appears to slow men down (Table 3, Model 4 and Figure 1). This supports early conceptualizations of women's entrepreneurship where business relationships are integrated, rather than separated from family, societal and personal relationships. Here women perceive their businesses as "cooperative networks of relationships" rather than separate economic units and so are likely to be more comfortable assessing familiar strong-tie relationships [Brush, 1992, p. 16].

\subsection{Gender and the effect of university support}

Our findings illustrate the importance of weak university level contacts for enterprising nascent entrepreneurs. Some studies have found that student exposure to entrepreneurial education has a positive impact on students' desire to engage in an entrepreneurship career as well as their perceptions of the feasibility of this type of career [Peterman, Kennedy, 2003; Lyons, Zhang, 2018]. The increasingly popular "business generation model" of entrepreneurial education focuses on the universities fostering the necessary conditions for organizational emergence [Bergmann, Hundt, Sternberg, 2016; Laukkanen, 2000]. In many university settings, students not only learn about new ventures but they also must be operationally involved in a feasible business concept, and become embedded in the real business context. This suggests that the mentoring, advice, contacts and in some cases actual financing of university students in the process of starting a new venture are not only of vital importance, but, as our findings suggest, result from a network of weak ties.

Surprisingly, we found that women made better use of the university-level weak tie networks than do men. Our expectation was that, given homophily effects, men would find it easier to participate in, and hence gain resources from, the mostly all male networks provided by the university, and hence they 
would make more progress through the venturing process. Our findings however confirm that women not only differentially gain more benefits from access to their strong tie, familial relationships to help them make progress through the venturing process, but that this effect also holds true for their weaker university-level networks as well. This finding corresponds with results from [Aldrich, Elam, Reese, 1997; Watson, 2011], who found that women entrepreneurs were as successful as men in activating networks involving financial, business loans, and expert advice.

Alternatively, one can argue it is not that women are more effective in utilizing their connections to foster the process of new venture creation, but that social support is more important for young women than for young men. Recall that the women nascent entrepreneurs in our sample were engaged in significantly fewer start-up activities compared to their male counterparts. Social support of any kind, however, can provide a significantly stronger boost in the start-up activity of women, compared to men. Entrepreneurship is still more likely to be seen as a male preserve and therefore less congruent with the social roles ascribed to women [Eagly, Wood, Diekman, 2000; Cochran, 2019]. In addition, women may follow a different approach in the set-up of their nascent ventures. Instead of an economic entity designed to achieve profit through economic advantage, women have been argued to perceive their businesses as "cooperative networks of relationships" in which business relationships are integrated rather than separated from family, societal, and personal factors [Brush, 1992; Carter, Brush 2004]. Thus, social approbation and support, both from strong and weak ties, is more critical for the start-up activities of women.

It should be noted also that overall the students in our sample did not make good use of the networking opportunities offered by their universities. The average student in our sample participated in one of five potential networking and/or mentoring activities, and women were less engaged in these initiatives than men were. Only $3.38 \%$ of our sample took advantage of all activities offered by their universities.

One strategy that women nascent entrepreneurs can adopt to further overcome issues of homophily is to have greater diversity in their networks [Weiler, Bernasek, 2001]. Research suggests that having a diverse or large set of ties in their network may help women entrepreneurs connect to different parts of a social system and open information channels inaccessible to those women with a small set of immediate network ties [Carter et al., 2003]. Empirical evidence from in-depth interviews with women entrepreneurs also suggests that while all-female informal networks provide critical support to early stage venture owners, over the long run, women come to view such networks as holding less worth in assisting them to develop and grow their business [Hampton, Cooper, McGowan, 2009]. Other recent case-based research highlights young women entrepreneurs' desire for networks to be "much more sensitive to the needs of young people, and young women in particular" [McGowan et al., 2015, p. 655].

\section{FUTURE RESEARCH, IMPLICATIONS, AND CONCLUSIONS}

Our study is not without limitations, which need to be borne in mind when interpreting its results. Although the GUESSS project is a panel study at the country level, the specific data utilized in this study were crosssectional, which does not allow us to identify causal relationships between social networks and the young nascent entrepreneurs progress through the venturing process. In addition, our sample is restricted to students. An interesting extension to this study would be to compare the start-up activities of university students with the start-up activities of recent university graduates. Moreover, because we were interested in the effect of different types of networks on nascent entrepreneurship, 
we examined only a subset of the university initiatives in support of student entrepreneurship. We encourage future studies to explore other ways in which universities can support their entrepreneurially-minded female students, for example by providingmakerspaces, collaborative labs, design studios, or nascent firm incubators. Finally, it should also be borne in mind that we have a sample of educated young men and women. Recent surveys of youth entrepreneurship report rising education levels [Schøtt, Kew, Cheraghi, 2015]. Still, generalizations to the general population of young nascent entrepreneurs should be made with caution.

We also followed convention and assumed a linear start-up process where young entrepreneurs receive support from their families and university, and then engage in start-up activities. However, there is some evidence that suggests that new venture creation may be a cyclical process, which is not reflected in our cross-sectional data (see, for example: [Blank, 2013]).

Finally, our sampling procedure, as discussed in the methods section, was not a truly randomized one. Although the large sample size minimizes the likelihood that the data collection procedures would compromise the generalizability of the findings to the population of interest in the study, future research, based on randomized sampling, can offer a robust and generalizable corroboration of our findings.

Limitations notwithstanding, our study demonstrates that entrepreneurial students are embedded in a social context that consists of their family and their university. In addition, we find that for women, this support matters more in their progress in the venturing process. These findings have important implications for families, universities, and for aspiring young entrepreneurs.

\section{REFERENCES}

Al-Dajani H., Marlow S. 2010. Impact of women's home-based enterprise on family dy-
For families, our findings suggest that access to the family's social capital is important for all young student entrepreneurs, but is especially important for women. Given norms of reciprocity, families should be willing to help their younger members navigate the maze of start-up activities by providing them with access to necessary resources.

For universities, this research suggests that educational institutions play an important role by supplying students with networking events, business plan competitions, mentoring, and sometimes even seed funding. All of these are critical to developing the contacts and connections needed to start a new venture. However, schools could also add workshops and networking seminars to their offerings. This would increase student awareness of networking and mentoring opportunities available through school and help students to learn the skills which are necessary to effectively manage diverse networks and contacts.

Finally, for aspiring young entrepreneurs, this research is a reminder of the importance of drawing on all forms or social resources, from family to those developed at the university, to gain access to necessary resources to start the new venture. Our findings indicate that, at least at the university level, all forms of support, family, and university matter more for women nascent entrepreneurs than for men. Given the importance of entrepreneurship to the career goals of university students, all students need to use the networks at their disposal to further their progress in the venturing process. In sum, our study adds to the ongoing conversation around women's entrepreneurship, by focusing on the context of social networks. It is our hope that other researchers will join in and enrich this conversation.

namics: Evidence from Jordan. International Small Business Journal 28 (5): 470-486.

PЖM 18 (2): 127-154 (2020) 
Aldrich H. E. 1989. Networking among women entrepreneurs. In: O. Hagen, C. Rivchum, D. Sexton (eds). Women Owned Businesses, 103-132. Praeger: N.Y.

Aldrich H. E., Cliff J. E. 2003. The pervasive effects of family on entrepreneurship: Toward a family embeddedness perspective. Journal of Business Venturing 18 (5): 573596.

Aldrich H. E., Elam A. B., Reese P. R. 1997. Strong ties, weak ties, and strangers: Do women business owners differ from men in their use of networking to obtain assistance? In: S. Birley, I. MacMillan (eds). Entrepreneurship in a Global Context, 1-25. Routledge: London.

Aldrich H. E., Sakano T. 1995. Unbroken ties: How the personal networks of Japanese business owners compare to those in other nations. In: M. Fruin (ed.). Networks and Markets, 17-45. Oxford University Press: N.Y.

Aldrich H. E., Reese P. R., Dubini P. 1989. Women on the verge of a breakthrough: Networking among entrepreneurs in the United States and Italy. Entrepreneurship \& Regional Development 1 (4): 339-356.

Aldrich H. E., Zimmer C. 1986. Entrepreneurship through social networks. In: D. L. Sexton, R. W. Smilor (eds). The Art and Science of Entrepreneurship, 3-23. Ballinger: Cambridge, MA.

Alsos G. A., Carter S., Ljunggren E. 2014. Kinship and business: How entrepreneurial households facilitate business growth. Entrepreneurship \& Regional Development $\mathbf{2 6}$ (1-2): 97-122.

Anderson A. R., Drakopoulou Dodd S., Jack S. L. 2012. Entrepreneurship as connecting: Some implications for theorising and practice. Management Decision 50 (5): 958-971.

Autio E., Keeley R. H., Klofsten M., Parker G.C., Hay M. 2001. Entrepreneurial intent among students in Scandinavia and in the USA. Enterprise and Innovation Management Studies 2 (2): 145-160.

Bergmann H., Hundt C., Sternberg R. 2016. What makes student entrepreneurs? On the relevance (and irrelevance) of the univer- sity and the regional context for student start-ups. Small Business Economics $\mathbf{4 7}$ (1): $53-76$.

Bernard J. 1981. The Female World. The Free Press/MacMillan Publishing Company: N.Y.

Blank S. 2013. Why the lean start-up changes everything. Harvard Business Review 91 (5): 63-72.

Bogatyreva K., Edelman L., Manolova T., Osiyevskyy O., Shirokova G. 2019. When do entrepreneurial intentions lead to actions? The role of national culture. Journal of Business Research 96: 309-321.

Brass D. J. 1985. Men's and women's networks: A study of interaction patterns and influence in an organization. Academy of Management Journal 28 (2): 327-343.

Brush C. G. 1992. Research on women business owners: Past trends, a new perspective and future directions. Entrepreneurship: Theory and Practice 16 (4): 5-31.

Brush C. G., Manolova T. S., Edelman L. F. 2008. Properties of emerging organizations: An empirical test. Journal of Business Venturing 23 (5): 547-566.

Burt R. S. 1992. Structural holes: the social structure of competition. Harvard University Press: Cambridge.

Burt R. S. 2004. Structural holes and good ideas. American Journal of Sociology $\mathbf{1 1 0}$ (2): 349-399.

Carey T. A., Flanagan D. J., Palmer T. B. 2010. An examination of university student entrepreneurial intentions by type of venture. Journal of Developmental Entrepreneurship 15 (4): 503-517.

Carter N. M., Brush C. G. 2004. Gender. In: W. B. Gartner (ed.). Handbook of Entrepreneurial Dynamics, 12-25. Sage Publications: Thousand Oaks, CA.

Carter N., Brush C., Greene P., Gatewood E., Hart M. 2003. Women entrepreneurs who break through to equity financing: The influence of human, social and financial capital. Venture Capital: An International Journal of Entrepreneurial Finance 5 (1): 1-28.

Carter N. M., Gartner W. B., Reynolds P. 1996. Exploring start-up sequences. Journal of Business Venturing 11 (3): 151-166. 
Carter N. M., Gartner W. B., Shaver K. G. 2004. Career reasons. In: W. B. Gartner, K. G. Shaver, N. M. Carter, P. D. Reynolds (eds). Handbook of Entrepreneurial Dynamics: The Process of Business Creation, 142-152. Sage Publications: Thousand Oaks, CA.

Cochran S.L. 2019. What's gender got to do with it? The experiences of U.S. women entrepreneurship students. Journal of Small Business Management 57 (S1): 111-129.

Cohen J., Cohen P., West S. G., Aiken L. S. 2003. Applied Multiple Regression/Correlation Analysis for the Behavioral Sciences. Lawrence Erlbaum Associates: Mahwah, NJ.

Coleman J. S. 1988. Social capital in the creation of human capital. American Journal of Sociology 94: 95-120.

Cromie S., Birley S. 1990. Networking by female business owners in Northern Ireland. Journal of Business Venturing 7 (3): 237251.

Dana L.-P., Gurau C., Light I., Muhammad N. 2020. Family, community, and ethnic capital as entrepreneurial resources: Toward an integrated model. Journal of Small Business Management. doi:10.1111/jsbm.12507

Davidsson P. 2006. Nascent entrepreneurship: Empirical studies and developments. Foundations and Trends® in Entrepreneurship 2 (1): 1-76.

Davidsson P., Honig B. 2003. The role of social and human capital among nascent entrepreneurs. Journal of Business Venturing 18 (3): 301-331.

Delmar F., Davidsson P. 2000. Where do they come from? Prevalence and characteristics of nascent entrepreneurs. Entrepreneurship \& Regional Development 12 (1): 1-23.

DiMaggio P., Louch H. 1998. Socially embedded consumer transactions: For what kinds of purchases do people most often use networks? American Sociological Review 63 (5): 619-637.

Eagly A. H., Wood W., Diekman A. B. 2000. Social role theory of sex differences and similarities: A current appraisal. In: T. Eckes, H. M. Trautner (eds). The Devel- opmental Social Psychology of Gender, 123-174. Erlbaum: Mahwah, NJ.

Edelman L. F., Manolova T. S., Shirokova G., Tsukanova T. 2016. The impact of family support on young entrepreneurs' start-up activities. Journal of Business Venturing 31 (4): 428-448.

Gartner W. B., Carter N. M., Reynolds P. 2004. Business start-up activities. In: W. B. Gartner, K. G. Shaver, N. M. Carter, P. D. Reynolds (eds). The Handbook of Entrepreneurial Dynamics: The Process of Organization Creation, 285-299. Sage Series: Newbury Park, CA.

Gilligan C. 1982. In a Different Voice. Harvard University Press: Boston.

Gouldner A. W. 1960. The norm of reciprocity: A preliminary statement. American Sociological Review 25 (2): 161-178.

Granovetter M. S. 1973. The strength of weak ties. American Journal of Sociology 78 (6): 1360-1380.

Granovetter M. S. 1985. Economic action and social structure: The problem of embeddedness. American Journal of Sociology 91 (3): 481-510.

Greve A., Salaff J. W. 2003. Social networks and entrepreneurship. Entrepreneurship Theory and Practice 28 (1): 1-22.

Haines V. A., Hurlbert J. S. 1992. Network range and health. Journal of Health and Social Behavior 33 (3): 254-266.

Hair J. F., Tatham R. L., Anderson R. E. 1998. Multivariate Data Analysis (5 ${ }^{\text {th }}$ ed.). Prentice Hall.

Hampton A., Cooper S., Mcgowan P. 2009. Female entrepreneurial networks and networking activity in technology-based ventures: An exploratory study. International Small Business Journal 27 (2): 193-214.

Hebert R. H., Link A. N. 1989. In search of the meaning of entrepreneurship. Small Business Economics 1: 39-49.

Hite J. M., Hesterly W. S. 2001. The evolution of firm networks: From emergence to early growth of the firm. Strategic Management Journal 22 (3): 275-286.

Ibarra H. 1993. Personal networks of women and minorities in management: A concep- 
tual framework. Academy of Management Review 18 (1): 56-87.

Kanter R. M. 1977. Some effects of proportions on group life: Skewed sex ratios and responses to token women. American Journal of Sociology 82 (5): 965-990.

Katz J., Williams M. P. 1997. Gender, selfemployment and weak-tie networking through formal organizations. Entrepreneurship \& Regional Development 9 (3): 183-198.

Karra N., Tracey P., Phillips N. 2006. Altruism and agency in the family firm: Exploring the role of family, kinship, and ethnicity. Entrepreneurship Theory and Practice 30 (6): 861-877.

Kolvereid L. 1996. Organizational employment versus self-employment: Reasons for career choice intentions. Entrepreneurship Theory and Practice 20 (3): 23-31.

Krueger N. F., Reilly M. D., Carsrud A. L. 2000. Competing models of entrepreneurial intentions. Journal of Business Venturing 15 (5-6): 411-432.

Laspita S., Breugst N., Heblich S., Patzelt H. 2012. Intergenerational transmission of entrepreneurial intentions. Journal of Business Venturing 27 (4): 414-435.

Laukkanen M. 2000. Exploring alternative approaches in high-level entrepreneurship education: Creating micro-mechanisms for endogenous regional growth. Entrepreneurship and Regional Development 12 (1): 25-47.

Lichtenstein B. B., Carter N. M., Dooley K. J., Gartner W. B. 2007. Complexity dynamics of nascent entrepreneurship. Journal of Business Venturing 22 (2): 236-261.

Lincoln J. R., Miller J. 1979. Work and friendship ties in organizations: A comparative analysis of relation networks. Administrative Science Quarterly 24 (2): 181-199.

Lyons E., Zhang L. 2018. Who does (not) benefit from entrepreneurship programs? Strategic Management Journal 39 (1): 85-112

Marsden P. V. 1988. Homogeneity in confiding relations. Social Networks 10 (1): 57-76.

McGowan P., Cooper S., Durkin M., O'Kane C. 2015. The influence of social and human capital in developing young women as entrepreneurial business leaders. Journal of
Small Business Management 53 (3): 645661.

McIntosh J. C., Islam S. 2010. Beyond the veil: The influence of Islam on female entrepreneurship in a conservative Muslim context. International Management Review 6 (1): 102-111.

McKeever E., Jack S., Anderson A. 2015. Embedded entrepreneurship in the creative reconstruction of place. Journal of Business Venturing 30 (1): 50-65.

McPherson M., Smith-Lovin L., Cook J. M. 2001. Birds of a feather: Homophily in social networks. Annual Review of Sociology 27: 415-444.

Meoli A., Fini R., Sobrero M., Wiklund J. 2020. How entrepreneurial intentions influence entrepreneurial career choices: The moderating influence of social context. Journal of Business Venturing 35 (3). In-press: https://doi.org/10.1016/j. jbusvent.2019.105982

Morris M., Shirokova G., Tsukanova T. 2017. Student entrepreneurship and the university ecosystem: A multi-country empirical exploration. European Journal of International Management 11 (1): 65-85.

Nielsen S. L., Lassen A. H. 2012. Identity in entrepreneurship effectuation theory: A supplementary framework. International Entrepreneurship and Management Journal 8 (3): 373-389.

Peterman N. E., Kennedy J. 2003. Enterprise education: Influencing students' perceptions of entrepreneurship. Entrepreneurship Theory and Practice 28 (2): 129-144.

Podsakoff P. M., MacKenzie S. B., Lee J.-Y., Podsakoff N. P. 2003. Common method bias in behavioral research: A critical review of the literature and recommended remedies. Journal of Applied Psychology 88 (5): 879903.

Rasmussen E. A., Mosey S., Wright M. 2015. The transformation of network ties to develop entrepreneurial competencies for university sin-offs. Entrepreneurship \& Regional Development 27 (7-8): 430-457.

Renzulli L.A., Aldrich H., Moody J. 2000. Family matters: Gender, networks, and en- 
trepreneurial outcomes. Social Forces $\mathbf{7 9}$ (2): $523-546$.

Reynolds P. D., Miller B. 1992. New firm gestation: Conception, birth and implications for research. Journal of Business Venturing 7 (5): 405-417.

Reynolds P. D., Storey J., Westhead P. 1994. Cross-national comparisons of the variation in new firm formation rates. Regional Studies 28 (4): 443-456.

Reynolds P. D. 2010. New firm creation in the United States: A PSED I overview. Foundations and Trends in Entrepreneurship 3 (1): 1-150.

Ruef M., Aldrich H. E., Carter N. M. 2003. The structure of founding teams: Homophily, strong ties, and isolation among US entrepreneurs. American Sociological Review 68 (2): 195-222.

Samuelsson M., Davidsson P. 2009. Does venture opportunity variation matter? Investigating systematic process differences between innovative and imitative new ventures. Small Business Economics 33 (2): 229-255.

Shagalkina M., Latukha M., Mitskevich E., Strogetskaya E. 2019. Factors of migration intentions of talented graduates from leading Russian universities. Russian Management Journal 17 (4): 445-466.

Shepherd D. 2015. Party on! A call for entrepreneurship research that is more interactive, activity based, cognitively hot, compassionate, and prosocial. Journal of Business Venturing 30 (4): 489-507.

Shepherd D., Wennberg K., Suddaby R., Wicklund J. 2019. What are we explaining? A review and agenda on initiating, engaging, performing, and contextualizing entrepreneurship. Journal of Management 45 (1): 159-196.

Schøtt T., Kew P., Cheraghi M. 2015. Future Potential: A GEM Perspective on Youth Entrepreneurship. Global Entrepreneurship Monitor. [Electronic resource]. http://www. gemconsortium.org/report/49200 (accessed: 26.04.2020).

Shirokova G., Bogatyreva K., Galkina T. 2014. Effectuation and causation: Relationship between university infrastructure and be- havioral choice in new venture creation by student-entrepreneurs. Russian Management Journal 12 (3): 59-86.

Sieger P., Fueglistaller U., Zellweger T. 2011. Entrepreneurial Intentions and Activities of Students Across the World. International Report on the GUESSS Project 2011. Swiss Research institute of Small Business and Entrepreneurship. University of St. Gallen.

Siemsen E., Roth A., Oliveira P. 2010. Common method bias in regression models with linear, quadratic, and interaction effects. Organizational Research Methods 13 (3): 456-476.

Sørensen J. B. 2007. Closure and exposure: Mechanisms in the intergenerational transmission of self-employment. In: M. Ruef, M. Lounsbury (eds). Research in the Sociology of Organizations, 83-124. Emerald Group Publishing Limited: Bradford.

Souitaris V., Zerbinati S., Al-Laham A. 2007. Do entrepreneurship programmes raise entrepreneurial intention of science and engineering students? The effect of learning, inspiration and resources. Journal of Business Venturing 22 (4): 566-591.

Steier L. 2007. New venture creation and organization: A familial sub-narrative. Journal of Business Research 60 (10): 10991107.

Watson J. 2011. Networking: Gender differences and the association with firm performance. International Small Business Journal 30 (5): 536-558.

Weiler S., Bernasek A. 2001. Dodging the glass ceiling? Networks and the new wave of women entrepreneurs. The Social Science Journal 38 (1): 85-103.

Weiss J., Anisimova T., Shirokova G. 2019. The transition of entrepreneurial intention into start-up behavior: The moderating role of regional social capital. International Small Business Journal 37 (5): 473-501.

Wegner D., Thomas E., Teixeira E. K., Maehler A. E. 2020. University entrepreneurial push strategy and students' entrepreneurial intention. International Journal of Entrepreneurship Behavior \& Research 26 (2): 307325. 
Wellman B., Wortley S. 1990. Different strokes from different folks: Community ties and social support. American Journal of Sociology 96 (3): 558-588.

Welter F. 2011. Contextualizing entrepreneurship - conceptual challenges and ways forward. Entrepreneurship Theory and Practice 35 (1): 165-184.
Zazdravnykh E. 2019. The historical effects of the regional entrepreneurial activity. Russian Management Journal 17 (1): 97-120.

Zellweger T., Sieger P., Halter F. 2011. Should I stay or should I go? Career choice intentions of students with family business background. Journal of Business Venturing 26 (5): 521-536.

Initial submission: May 2, 2020

Final version accepted: June 30, 2020

Контекст илеет значение: роль университета и сельи для нарождающихся лолодых предпринилателей

\section{Л. Ф. Эдельлан, Т. Манолова}

Департамент менеджмента, Университет Бентли, США

\section{Г. Широкова}

Институт «Высшая школа менеджмента», Санкт-Петербургский государственный университет, Россия; Санкт-Петербургская школа экономики и менеджмента, Национальный исследовательский университет «Высшая школа экономики», Россия

\section{Т. Цуканова}

Институт «Высшая школа менеджмента», Санкт-Петербургский государственный университет, Россия

Нарождающиеся предприниматели - это люди, которые вовлечены в деятельность, направленную на создание нового бизнеса. Во многих случаях эти действия приводят к успешному созданию компании, но иногда первоначальные идеи предпринимателя так и остаются нереализованными, потому что ему не удалось привлечь необходимые для создания бизнеса ресурсы. В статье изучается влияние семейного и университетского социального контекста на нарождающихся молодых предпринимателей. Результаты исследования, основанного на эмпирических данных международного проекта «Глобальное исследование предпринимательского духа студентов» (2011 г.), продемонстрировали, что и семья и университет оказывают существенное влияние на прогресс молодых предпринимателей при создании нового бизнеса, но при более детальном изучении были выявлены гендерные различия в этом процессе. Женщиныпредприниматели рассчитывают на поддержку со стороны семьи («сильные связи») и могут лучше, чем мужчины, использовать свои «слабые связи» с университетом при создании нового бизнеса. Таким образом, для женщин - нарождающихся предпринимателей оказались важны все виды социальной поддержки.

Ключевые слова: нарождающиеся женщины-предприниматели, деятельность по созданию стартапа, социальный контекст, поддержка университета, поддержка семьи, Глобальное исследование предпринимательского духа студентов.

JEL: A22, D83, L26. 
For citation: Edelman L. F., Manolova T., Shirokova G., Tsukanova T. 2020. Context matters: The importance of university and family for young nascent entrepreneurs. Russian Management Journal 18 (2): 127-154.

Статья поступила в редакиию 2 мая 2020 2. Принята к публикаиии 30 июня 2020 г. 